\title{
What was the ecological impact of a Trypillia megasite occupation? Multi-proxy palaeo-environmental investigations at Nebelivka, Ukraine
}

\author{
Bruce Albert ${ }^{1} \cdot \mathrm{Jim}_{\text {Innes }}{ }^{2} \cdot \mathrm{Konstantin} \mathrm{Krementskiy}^{3} \cdot$ Andrew R Millard $^{1} \cdot$ Bisserka Gaydarska $^{1} \cdot$ Marco Nebbia $^{1}$. \\ John Chapman ${ }^{1}$
}

Received: 19 July 2018 / Accepted: 17 April 2019 / Published online: 7 May 2019

(c) The Author(s) 2019

\begin{abstract}
Fine-resolution sampling of pollen, non-pollen palynomorphs and microcharcoal as well as sedimentological data in a 6-m sediment core were used to reconstruct both natural conditions and human impacts in the late fifth and early fourth millennia cal $\mathrm{BC}$ in the environs of the Nebelivka megasite in Kirovograd Oblast, Central Ukraine. This 238-ha site, dating to the Middle (or BII) Phase of the Trypillia culture, represents one of the first low-density urban establishments in Europe. Despite what was believed to be a sizable population, local human impacts reconstructed from the multi-proxy palaeo-ecological record were moderate in character. There was no positive evidence to indicate a depositional hiatus in the P1 core and no sign of a major ecological impact at any stage in the high-resolution record. The palaeo-ecological record indicates modest settlement agglomeration with less permanent populations rather than permanent populations of tens of thousands of people.
\end{abstract}

Keywords Trypillia group $\cdot$ Early urbanism $\cdot$ Palynology $\cdot$ Sedimentology $\cdot$ Human impacts

\section{Introduction}

\section{Archaeological background: the Trypillian megasite phenomenon}

The time-place distribution of the Cucuteni-Trypillia (or 'Tripolye' in the Russian literature) groups - two millennia (5000-2800 cal BC) and 250,000 $\mathrm{km}^{2}$ - makes them one of the largest and most long-lasting groups in 'Old Europe'

Communicated by W. Tinner.

Electronic supplementary material The online version of this article (https://doi.org/10.1007/s00334-019-00730-9) contains supplementary material, which is available to authorized users.

John Chapman

j.c.chapman@dur.ac.uk

1 Department of Archaeology, Durham University, Lower Mountjoy, South Rd, Durham DH1 3LE, UK

2 Department of Geography, Durham University, Lower Mountjoy, South Rd, Durham DH1 3LE, UK

3 Institute of Geography, University of California (UCLA), Los Angeles, CA 90095, USA
(Fig. 1). In much of Ukraine, Trypillia groups were the first farmers in the region. A late development within the Trypillia group was the emergence of so-called 'megasites' in the Uman region of central Ukraine, which constituted the largest sites in fourth millennium BC Europe (Videiko 2012). The five largest megasites comprise Taljanki at 320 ha, Nebelivka at 238 ha, Majdanetske at 200 ha, Tomashivka at 150-250 ha and Dobrovodi at 150 ha (Korvin-Piotrovskiy et al. 2012; Chapman et al. 2014a; Rassmann et al. 2014, 2016). The scale of these settlements raises questions about the social structures involved and the likely ecological impact of the population (Müller et al. 2016). These questions led to the establishment of an Anglo-Ukrainian project between Durham University and the Kyiv Institute of Archaeology (2009 and 2012-2016), with a fieldwork focus at the megasite of Nebelivka (Chapman and Videiko 2011; Chapman et al. 2014a, b; Gaydarska in press a).

The completion of the first plan of a megasite using modern geophysical prospection showed a total of 1,445 structures at Nebelivka (Chapman et al. 2014b) (Fig. 2). Ongoing modelling of over 80 AMS dates shows a settlement duration of not more than 2 centuries, c. $3950-3750 \mathrm{cal} \mathrm{BC}$; we are currently modelling the number of houses in coeval occupation with the aid of Bayesian analyses of these dates (Millard 


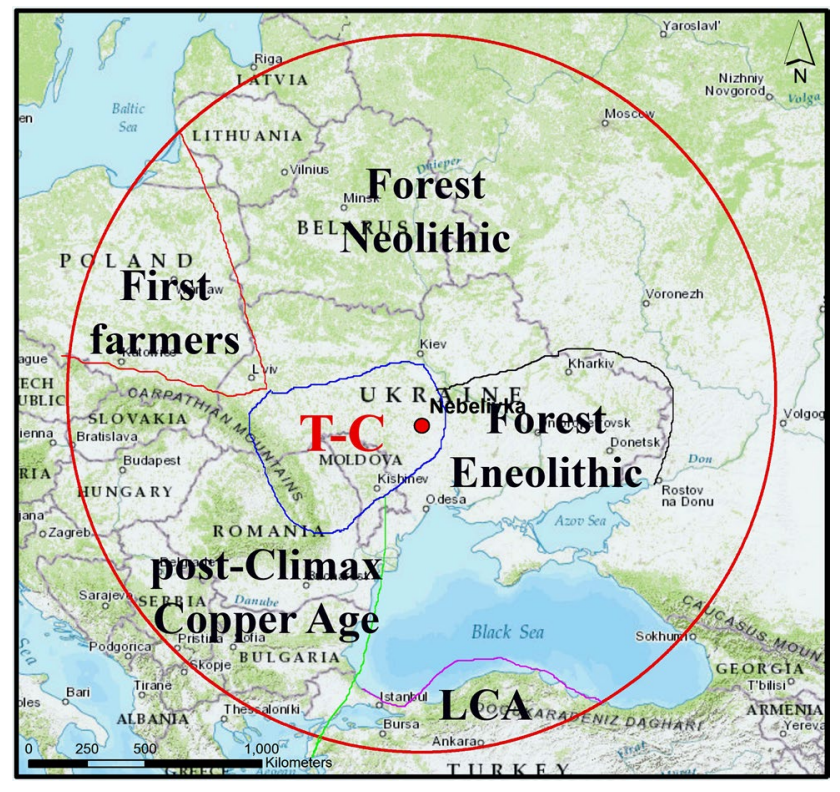

Fig. 1 Distribution of Cucuteni-Trypillia groups

2019, https://doi.org/10.5284/1047597, Section 4_9). The Nebelivka team is currently exploring the possibility of less permanent occupation through a Distributed Governance Model, a seasonal summer assembly place (the Assembly Model) or a pilgrimage site with seasonal population peaks (the Pilgrimage Model)—-three minimalist models involving no more than a few thousand people at the site throughout the year. In strong contrast, the Ukrainian-German team working at Majdanetske and Taljanki favour a maximalist model in which all megasite houses were occupied at the same time. At Majdanetske, over 3,000 structures are documented by geophysical prospection and limited excavation, leading to population estimates ranging from 12,000 to 46,000 people (Rassmann et al. 2014; Müller et al. 2016). These estimates of the density of occupation imply the possibility of state-level social structure at the same date as Uruk developments in the Fertile Crescent (Liverani 2006), with concomitant levels of impact on the local environment.

Investigations of the palaeo-environment at Nebelivka provide an excellent opportunity for testing the human impact of a megasite, the more so since the coring site is only $250 \mathrm{~m}$ from one edge of the megasite (ESM 1 Fig. 1). Previous investigations of Trypillia lifeways (Pashkevitch 1997, 2005; Pashkevych and Videiko 2006; Pashkevych 2012; Videiko 2013) indicate an expectation of five kinds of impact: (1) forest clearance to provide land for intensive or extensive farming, with timber for building the hundreds of houses as well as cooking and heating (Kruts 1990); (2) intensive charcoal concentrations marking the regular burning of houses at the end of their life-cycle (Chapman 2015); (3) agricultural and/or pastoral indicator species; (4) high soil erosion caused by megasite settlement which would have resulted in high sedimentation rates; and (5) the stress that a supposedly large site population would place on the water supply provided by a network of small streams. The aim of this article is to assess the scale of the human impact identified in the Nebelivka P1 core with a view to adjudicating between the 'minimalist' and 'maximalist' models of Trypillia settlement and lifeways.

\section{Palaeo-ecology of the forest-steppe and steppe}

There are few pollen studies from the forest steppe and steppe zones south of $50^{\circ} \mathrm{N}$ latitude in Ukraine and the region investigated here lacks well-dated studies (Harper 2016, 2017. Thermophilous mixed-oak woodlands, with high Corylus (hazel), Ulmus (elm), Tilia (lime), Quercus (oaks) and some Carpinus (hornbeam), existed during the warm and wet climate of the early Atlantic climatic period (fifth millennium $\mathrm{BC}$ ) in the forest-steppe zone of western Ukraine, based on data from Zones 1 and 2 of the Dovzhok swamp pollen diagram, Dniestr valley (Kremenetski 1995, 2003). In contrast, open environments are reconstructed for the Early Holocene at Myrne and Belolesye in southwestern Ukraine, based on lower levels of arboreal pollen (AP), and domination by herbs (NAP), followed by thermophilous mixed-oak woodland in the Middle Holocene (Pashkevych 2012). In southern Ukraine, similar open swampland sites such as Kardashinski in the Dniepr valley had lower AP in the Middle and Late Holocene, indicating a fully developed steppe beyond the broad-leaved forests of the floodplain. After $5000 \mathrm{BC}$, haline meadows and moisture stress are inferred at Kardashinski (Kremenetski 1995), while other records (e.g. the Heraklean Peninsula, Crimea) have multiple unconformities in this period which might relate to similar changes and show that cultivation occurred only late in the Holocene. In eastern Ukraine, as at Glubokoye, Atlantic conditions produced a mixed-oak woodland (Gerasimenko 1997), but evidence for subsequent dry conditions is poorly dated. By contrast, a drought c. 4500 вС was detected at Beresovskoye in the adjacent Upper Don River region, Russia (cf. Kremenetski et al. 1999; Novenko et al. 2012) followed by a wet phase after $4200 \mathrm{BC}$, several centuries before the occupation of Nebelivka.

\section{Methodological introduction}

An assessment of the scale of human impacts on the environment as well as natural changes in the Trypillian period at Nebelivka requires an overview of pollen taphonomy and the registration of agricultural indicators for this sediment core, which developed in a small alluvial basin. Importantly, pollen sites accumulating by hydrological transport exhibit different spectra compared to sites with aeolian transport. In 


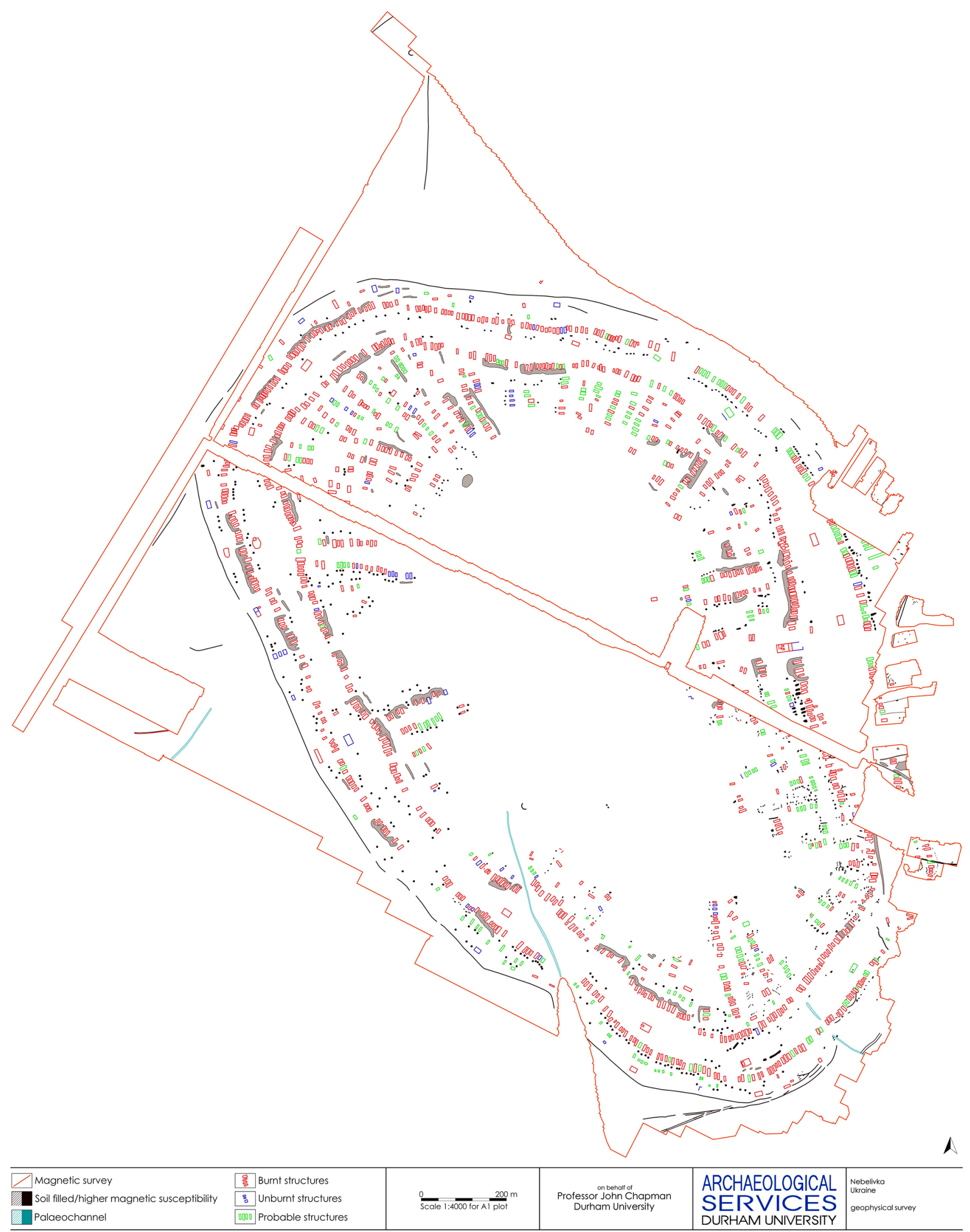

Fig. 2 Plan of Nebelivka megasite 
relation to the distance of vegetation stands and their pollen representation, they exhibit lower distance-decay (Brown et al. 2007). At sites on alluvial margins, the land-area supplying pollen may be more strictly limited to the basin itself, which is advantageous for interpretation of the pollen diagram (cf. Jacobson and Bradshaw 1981; Bradshaw and Webb 1985; Bradshaw et al. 2005).

Interpretation of cereal pollen levels in slack-water alluvial deposits at Nebelivka (as \% TLP) must take into account taphonomic influences such as hydrological transport, which entails much higher kinetic levels than air transport and thus much higher representation of pollen types with low production and poor transport, such as cereals, as well as lower distance-decay relationships with respect to vegetation representation in pollen diagrams (cf. Behre and Kučan 1986; Brown et al. 2007; Albert and Pokorný 2012). Factors favouring pollen preservation in low order drainages in particular include high water table and acidity (Albert 2007, 2011).

In a study of two pollen sites under contrasting taphonomic influence in the Peruc region of northern Bohemia (Czech Republic), it was found that the site of Vranský Potok, with its high hydrological pollen inputs, exhibited much higher cultivation pollen levels than the adjacent Zahaji site, where pollen was derived by aeolian transport from an area continuously occupied since the Neolithic (Albert and Pokorný 2012). This is an unsurprising result in view of the poor airborne transport efficiency of cereal pollen (Behre and Kučan 1986; Abraham and Kozáková 2012). Thus, at hydrological sites in farmed drainage basins such as Nebelivka, higher deposition of cereal pollen is to be expected because water will transport such grains more effectively over distance than air.

With respect to particular percentage values associated with intensive cultivation in small basins in chernozem zones of Temperate Europe, the case of Vranský Potok, Czech Republic, provides a close analogue with respect to both sedimentation regime and ecological conditions (Albert and Pokorný 2012). In the latter basin, well-represented Medieval-period sediments are correlated with a nearly complete exploitation of primary arable soils. Here, total cereal pollen levels, including Triticum, Hordeum, Secale cereale and the general Cerealia type range between $10 \%$ and $15 \%$ (TLP). The level of cereal pollen in pre-Medieval sediments is much lower, with values no greater than $4 \%$ even during periods of higher settlement intensity such as the Late Bronze Age.

These results translate into the following generalised predictions for Nebelivka: cereal pollen levels around 4\% (TLP) or less would suggest extensive cultivation, pollen levels around 5\% would be typical of short-fallow agriculture, while total cereal pollen of 10-15\% TLP would suggest major, extensive cultivation of interfluve soils. This third scenario might be an expected result of very high population levels at the megasite, for example, with permanent populations in excess of 10,000 individuals. The three cultivation scenarios would also yield predictors of sedimentological change, in particular erosion. For example, we would expect the third scenario of very intensive land use to induce significant increases in sand and larger particle sizes, although natural vectors of deforestation, including drought, should not be forgotten.

\section{Study region and materials: pollen core $P 1$ and Nebelivka megasite}

The target region for palaeoecological reconstruction was the environs of the Trypillia megasite of Nebelivka, near the village of Nebelivka, Kirovograd Oblast, Ukraine. The geology consists of Pre-Cambrian granite and gabbro. This bedrock is deeply incised by valleys, including all tributaries to the local stream network. The study is focused in the valley of an unnamed tributary with steep transportational slopes (c. $30^{\circ}$ ) on the eastern edge of the megasite. Interfluves are draped with Pleistocene loess of variable thickness-typically $1.5 \mathrm{~m}$ but deeper in gulley fills. Carbonate-rich soils, including chernozems, developed out of the loess at various points in the Holocene. Climate is temperate and moderately continental, with mean July temperature of $20^{\circ} \mathrm{C}$ and a mean January temperature of $-6{ }^{\circ} \mathrm{C}$, mean annual precipitation being c. $550 \mathrm{~mm}$.

Vegetation in the study region is classified as foreststeppe, although steppe taxa are azonal in distribution, with Stipa capillata (feather grass) being limited to southern exposures of steep slopes of stream and river valleys. The interfluves today are largely cultivated with a variety of noncereal crops, with forested boundaries of large fields also consisting of many introduced species. Primary mixed-oak woodland with Tilia cordata elements is found at the southeastern edges of the Nebelivka Cooperative Farm in the direction of Borschova village, where a forest preserve is maintained by the Department of Environment, Kirovograd County Council (ESM 1 Fig. 1).

The study focuses on Holocene sediments in a 6-m sediment core where pollen is preserved under reducing and neutral conditions, designated $\mathrm{P} 1$ and located at $48^{\circ} 38^{\prime} 59.4^{\prime \prime} \mathrm{N}$ $30^{\circ} 33^{\prime} 38.1^{\prime \prime}$ E (ESM 1 Fig. 1). The core site was identified based on prior experience of alluvial pollen work in smallorder drainages, with the help of high resolution militaryquality topographic maps at 1:10,000 scale provided by the Kirovograd regional government. Site P1 represents an ideal balance between water table and sedimentation potential on one hand, and lower erosional potential on the other. The core was taken at the south-east edge of a small basin c. $200 \mathrm{~m}$ in length and c. $80 \mathrm{~m}$ in width. The topography indicates that the coring site was an alluvial site rather 
than a cut-off side-channel with fen or bog characteristics. On the west side of the basin, nearest the megasite, slopes approached $30^{\circ}$ - the steepest slopes of any area on the edge of the megasite-with more gradual slopes of $15-20^{\circ}$ on the east side of the valley. No artifacts were found in the basin and its environs during fieldwalking in 2009 but in the upper levels of the core, at 4,900-4,000 $\mathrm{mm}$ depth, small $(1-10 \mathrm{~mm})$ daub fragments are occasionally observed, indicating mass movement (colluviation) of material down slope following the megasite occupation period.

\section{Methods}

Sediments were extracted by a Cobra corer with a 1-m window sampler with plastic sampling tubes. Six cores were extracted with no compression being noted in sediments. Fine-resolution pollen analysis (Turner and Peglar 1988) was considered necessary in order to reconstruct a finetemporal vegetation history and refine the age-depth model. A total of 89 samples for pollen analysis was taken with a scalpel at $5 \mathrm{~mm}$ intervals in sediment core P1, from 4,900 to 5,340 $\mathrm{mm}$ depth. They consisted of reduced, organicrich minerogenic fines. Samples for dating were derived in bulk from the sediment core given an absence of observable microfossil material, and used both humate and 'pollen' materials; the latter contained micro-elements of leafy and ligneous detritus according to weakly acetolysed pollen samples. They were processed at the Geography Department, Durham University, using standard techniques (Moore et al. 1991) with hot $\mathrm{HCl}$, hot $\mathrm{KOH}$ (using a $175 \mathrm{~mm}$ mesh sieve) and hot HF for an extended period of time. Tablets containing a spike of c. 18,300 exotic Lycopodium spores (Stockmarr 1971) were added at the $\mathrm{HCl}$ stage to enable the calculation of pollen and microcharcoal concentrations. Samples were then subjected to acetolysis for $60 \mathrm{~s}$, followed by washing, dehydration in ethanol and storage in silicone oil, which was the mounting medium for microscope slides (Fægri et al. 1989).

Pollen and non-pollen palynomorph (NPP) analyses were conducted at $\times 400$ magnification for scanning purposes and at $\times 1,000$ (in anisol) for all cereals. Identification of pollen follows Moore et al. (1991) and of NPPs follows van Hoeve and Hendrikse (1998). The long diameter of all cereals and Poaceae was measured in order to define relative incidence of large wild Poaceae as well as ambiguous grains (Andersen 1979; Joly et al. 2007). The latter include large wild grass types as well as potential cereals (not included in the cereal pollen sum), represented by the group 34 to $37 \mu \mathrm{m}$ (in fact, many Hordeum vulgare and most Triticum monococcum grains). Poaceae pollen with exceptionally large outer annular diameters was classified as cf. Glyceria (Albert and Innes 2015). Glyceria maxima pollen, native to Ukraine, has furthermore been sampled by one of the authors (BWA) from collections at the Uman Botanical Garden in central Ukraine, with results similar to those of Albert and Innes (2015). In addition, a comprehensive survey of pollen morphologies of azonal steppe grasses (esp. genus Stipa, and including $S$. capillata, S. pennata, S. lessingiana, S. dasyphilla, S. tirsa, S. pulcherrima, S. borysthenica and $S$. ucrainica) was made based on field collections (kindly assisted by T. Adrienko) throughout the Kirovograd region with a view to comparisons with cereals. These species' palynomorphs show a main size distribution in the range 31-33 $\mu \mathrm{m}$ diameter, with an isolated grain of Stipa ucrainica measuring $36 \mu \mathrm{m}$. Problems of confusion of such wild grasses with cereals with the exception of einkorn wheat are thus deemed minimal, although Poaceae larger than $30 \mu \mathrm{m}$ but sub-cereal-sized are deemed more likely to belong to steppe species (or in some cases, the native aquatic Glyceria maxima). Stratigraphically constrained incremental sum of squares cluster analysis according to percentage data of all pollen types, as facilitated by CONISS (Grimm 1987), was used to identify pollen zones.

All microcharcoal elements of 51-175 $\mu \mathrm{m}$ long diameter were counted (Robinson 1984) until a sub-total of 50 Lycopodium (spike) was encountered (100+elements) and individually measured. Three size classes were employed (long diameter: 51-75 $\mu \mathrm{m}, 76-125 \mu \mathrm{m}, 126-175 \mu \mathrm{m}$ ), which may reflect aeolian fallout characteristics and hence factors of distance from original fire sources (Blackford 2000). A further possibility exists that these elements are secondarily derived from A-horizon sources of earlier sedimentation, in addition to microcharcoal that is deposited contemporary with sedimentation (contemporary fire sources).

A total of 36 Loss on Ignition (LoI) samples was processed at the Department of Geography, University of California at Los Angeles. These were dried and then heated at $550{ }^{\circ} \mathrm{C}$ for $24 \mathrm{~h}$. Dry weight lost on ignition was assessed and the ashed sample employed for carbonate analysis. Carbonate samples were weighed at the ash stage, and heated at $950{ }^{\circ} \mathrm{C}$ for $4 \mathrm{~h}$, and the weight loss differential multiplied by $1.36\left(\mathrm{CO}_{2}\right.$ vs. $\left.\mathrm{CO}_{3} \mathrm{~g} / \mathrm{mol}\right)$ to derive the carbonate content. This content is an important climate indicator through the definition of calcium carbonate precipitation and deposition episodes that occur as a result of periodic drought in the region.

Residual sediments from the analyzed section from core P1 not employed for AMS dates and pollen analysis were subjected to particle size analysis using a Beckman Coulter LS 13320 Laser Diffraction Particle Size Analyzer in the Department of Geography, Durham University. This uses laser diffraction to measure the size distribution of particles from 0.4 to 2,000 $\mu \mathrm{m}$ (diameter), and also uses a PIDS detection system, which further uses polarized light to measure particles in the range $0.04-0.4 \mu \mathrm{m}$. 
A radiocarbon chronology was constructed. Dating was conducted on 11 samples from the core. An iterative approach was used to focus efforts on the sections most likely to be coeval with the megasite occupation. Where samples contained both fine organic material and plant macrofossils, the fine organic material was dated as the macrofossils appeared to be roots intruding from plants growing at a higher level. Initial samples were sieved to remove macrofossils and the fine organic sediment fraction was dated. As some dates produced by this approach were out of chronostratigraphic order, later dates were measured on 'pollen residue': the fine residue prepared by Durham University Department of Geography. The laboratory method varies from standard pollen analysis in the omission of oxidizers (thus, most residue in 'pollen' dates is actually plant cellulose) and the omission of sample preparation in a silicone matrix. All samples isolated by these physical methods were subjected to the standard acid-base-acid treatment of the dating laboratory (Beta Analytic or Poznań), before combustion and conversion to graphite for accelerator mass spectrometer measurement of the radiocarbon date. All results are calibrated using IntCal13 (Reimer et al. 2013) and reported according to international conventions (Millard 2014).

Chronology construction was performed in the OxCal software (Bronk Ramsey 2009a) using the P_Sequence age depth model with variable deposition rate parameter, $\mathrm{k}$ (Bronk Ramsey 2008; Bronk Ramsey and Lee 2013), and a vague prior probability for $\log (\mathrm{k})$ uniform on -3 to 1 . Outlier analysis with a prior outlier probability of $10 \%$ (Bronk Ramsey 2009b) was used in a preliminary model with low resolution interpolation to confirm which dates were out of sequence, and those definitively identified as outliers, with posterior probability $100 \%$, were omitted from the final modelling. The chronology was interpolated at $5 \mathrm{~mm}$ intervals to match the pollen sampling, and durations and sedimentation rates for each pollen zone were calculated.

\section{Results}

\section{Sediments}

The Trypillian age sediments in Core P1 are described in ESM 1 Table 1 according to Troels-Smith (1955). Fine sediments, mostly silt and clay, predominated in core P1, with the sole exception of a colluvial layer $(5,340-5,470 \mathrm{~mm})$ several centuries older than the megasite occupation. Here, Munsell values were lighter due to carbonates presumably deriving from local soils, and sediments included gabbro pebbles, indicating a much higher energy depositional environment relative to other core sediments. These results compare well with results of particle size analyses from the
Beckman Coulter apparatus (ESM 1 Fig. 2), with consistent values of about $75 \%$ silt, $20 \%$ clay and only $5 \%$ sand in sediments described as fines. Importantly, no breaks in this sequence which would have been suggestive of a hiatus are noted in the sediments of the central part of the P1 core. The rate of sedimentation as estimated by the age-depth model (see below) shows a lower rate in Zones 4-8.

Results of Loss on Ignition (LoI) analyses of core P1 sediments 5,000 to 6,000 $\mathrm{mm}$ are shown in ESM 1 Fig. 3 and ESM 1 Table 2. These values indicate the percentage of available organic matter in the sediments, with high values representing biologically more productive soil environments. Average organic contents are high $(>4 \%)$ ranging from 2.40 to $7.74 \%$, indicating a significant but variable input of organic matter into the sediments from local vegetation and eroded soils. These values are somewhat below those found in North Pontic chernozems today (Wilhelmy 1950), although similar organic carbon values (c. 5\%) are found in the azonal chernozems of Central Europe, where steppe vegetation is also azonal (Eckmeier et al. 2007; Hejcman et al. 2013). In the core depths bracketing the megasite occupation $(5,250-5,050 \mathrm{~mm})$, the organic values remained steady at c. $4 \%$, with the exception of one spike of $10 \%$ at depth 5,155 mm (Pollen Zone 4).

Particle size analysis of the central part of core P1 was conducted at intervals of $5 \mathrm{~mm}$ for depths 5,200 to $5,050 \mathrm{~mm}$, with six missing depths-samples could not be taken in certain parts of the core because all of the material had been used up for other analyses (ESM 1 Fig. 3). The silt fraction was dominant in every sample, with clay contents varying little and sand peaks up to $18 \%$ found at depths of 5,165, 5,050-5,145, 5,125 and 5,065 mm. This overall consistency suggests that there was no input of reworked material.

Results of carbonate analyses in the core P1 sediments generally show low carbonate content (c. 1-2\%), with no exceptions in the central layers of the core but with the important exception of the colluvial horizon around 5,350 to $5,450 \mathrm{~mm}$. In the colluvium, the much higher $(20 \%)$ relative carbonate content indicates greater levels of erosion from the carbonate-rich soils in the period preceding the fineresolution pollen sequence.

The overall conclusion from these sedimentological data is that there is no positive evidence in favour of a hiatus in core $\mathrm{P} 1$.

\section{Dating}

Initial modelling with all dates and outlier analysis (using the code in ESM 2) showed that with a prior probability before modelling of $10 \%$ on each date being an outlier, the posterior probabilities were either acceptably low (six were less than 5\%, one was 19\%) or extremely high (ESM 1 
Tables 3-4). The three outlier dates, Beta-407558 on 'pollen residue' at $5,140 \mathrm{~mm}$, Beta- 403913 at $4,990 \mathrm{~mm}$ on 'pollen', and Beta-384081 at 4,890 mm on fine organic sediment, with $100 \%$ chance of being outlier were omitted from further modelling. These three dates are very similar, and pass a Ward and Wilson (1978) test for lack of significant difference $\left(\mathrm{T}=4.8, \chi_{2 ; 0.05}^{2}=6.0\right)$ to give a combined date of $5,637 \pm 18$ вР (4540-4390 cal вс at $95 \%$ probability), even though they are on two different organic fractions. This suggests a common source for the carbon in these samples, and the date is approximately that of the modelled date of the colluvium at a depth of c. 5,450 to $5,350 \mathrm{~mm}$.

The modelled chronology using the eight accepted radiocarbon dates is shown in Fig. 3 and ESM 1 Fig. 4). Preliminary modelling of the 80 radiocarbon dates from the Nebelivka megasite suggests that it started at 3980-3870 cal BC $(90.0 \%)$ or $3860-3820 \mathrm{cal} \mathrm{BC}(5.4 \%)$ (modal date $3950 \mathrm{cal}$ BC), and ended 3870-3750 cal вс (95.4\%) (modal date $3750 \mathrm{cal}$ BC). ESM 1 Table 4 shows the dates for the start and end of each pollen zone, showing that the occupation of the megasite may have started as early as Pollen Zone 4

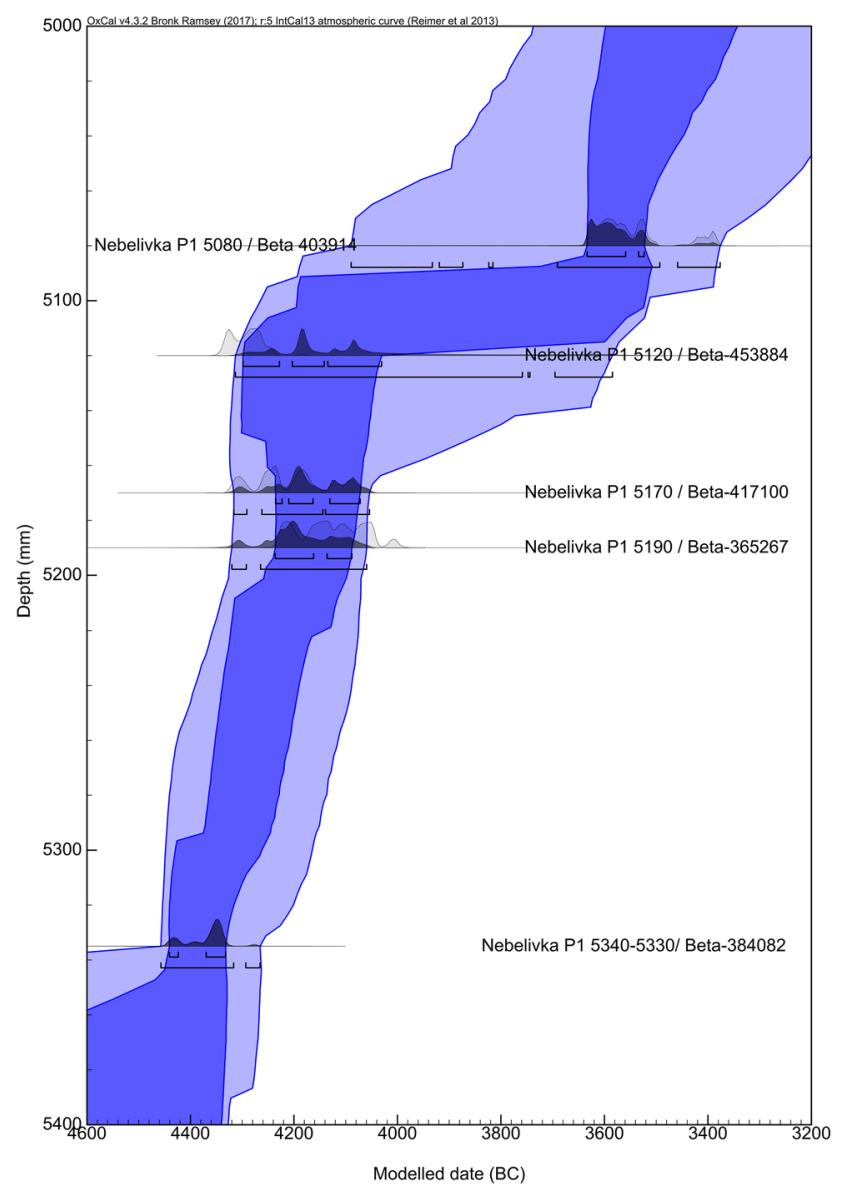

Fig. 3 Age-depth model for the central part of the diagram and ended maybe as late as Zone 6, with the most probable period being Zone 5 .

\section{Results: pollen zonation}

Pollen samples from core P1 exhibit concentration values exceeding 20,000 grains $/ \mathrm{cm}^{3}$, with reduced sedimentation rates in Zone 4 leading to maximum values of c. 200,000 grains $/ \mathrm{cm}^{3}$. The pollen is pristine and well-preserved, and a total of c. 31,000 grains in 89 samples were counted, not including NPPs, or an average of 325 grains per sample. The CONISS programme (Grimm 1987) allows the definition of eight pollen zones (Figs. 4, 5; ESM 1 Figs. 5-7). Each zone is described with characteristic species, their changes through the zone, a consideration of the representation of species such as Tilia and the Asteraceae, and an indication of when species are clearly established with pollen above the rational limit (viz., when pollen curves rise to consistently high percentages) rather than the earlier empirical limit (viz., when a pollen type becomes consistently present but in low frequencies). The median age estimates for the start and end of each zone are given here as an indication of the temporal placement, but the $95.4 \%$ probability ranges are mostly about 3 centuries wide, as shown in Table 1 with the principal characteristics of the Nebelivka pollen Zones 1-8.

\section{Discussion}

\section{Evaluation of depositional hypotheses}

In this article, our aim is to use our investigations of the palaeo-environment at Nebelivka to test the human impact of a megasite occupation in terms of the two explanatory models of Trypillia settlement and lifeways-the 'minimalist' view (low populations, seasonal or permanent settlement but with low numbers of coeval houses throughout the occupation) and the 'maximalist' view (high populations, long-term, permanent occupation with all houses occupied near the end of the occupation). However, the ambiguities in the age-depth model (see below) and the possible absence of the predicted environmental impact of human populations led us to consider two hypotheses concerning sedimentation in the small valley east of the megasite: the Hiatus Hypothesis, in which sediments contemporary with the megasite occupation are absent due to an interruption in sedimentation or subsequent erosion, and the self-explanatory Continuous Sedimentation Hypothesis. In addition to a detailed consideration of the age-depth model, adjudication between these two hypotheses requires a clear characterisation of sedimentation in the valley in Trypillia times, including particle size analysis and loss on ignition studies of the core layers and the presence/absence of a buried A-horizon, as well as consideration 
Fig. 4 Diagram of selected pollen taxa; zonation according to CONISS

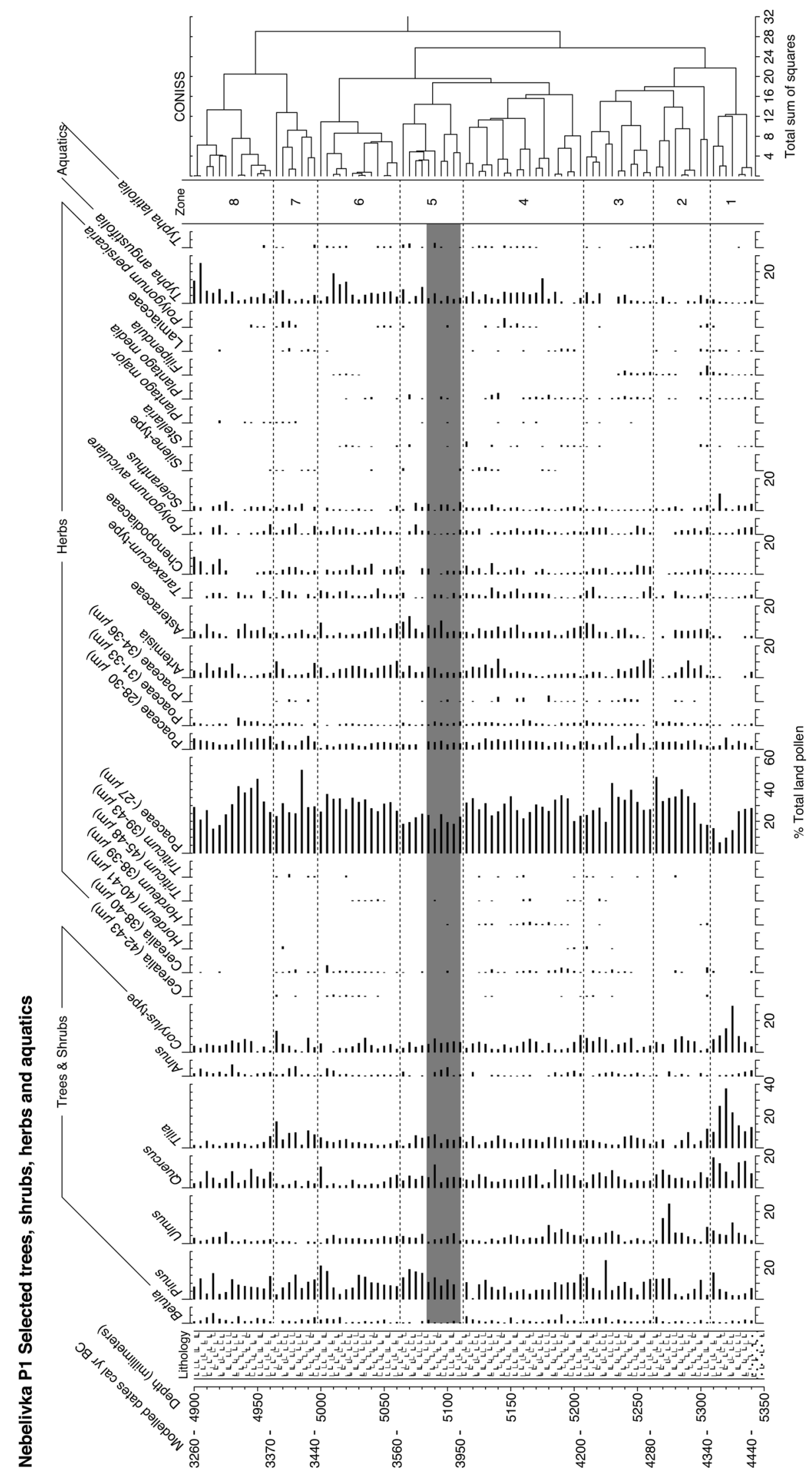




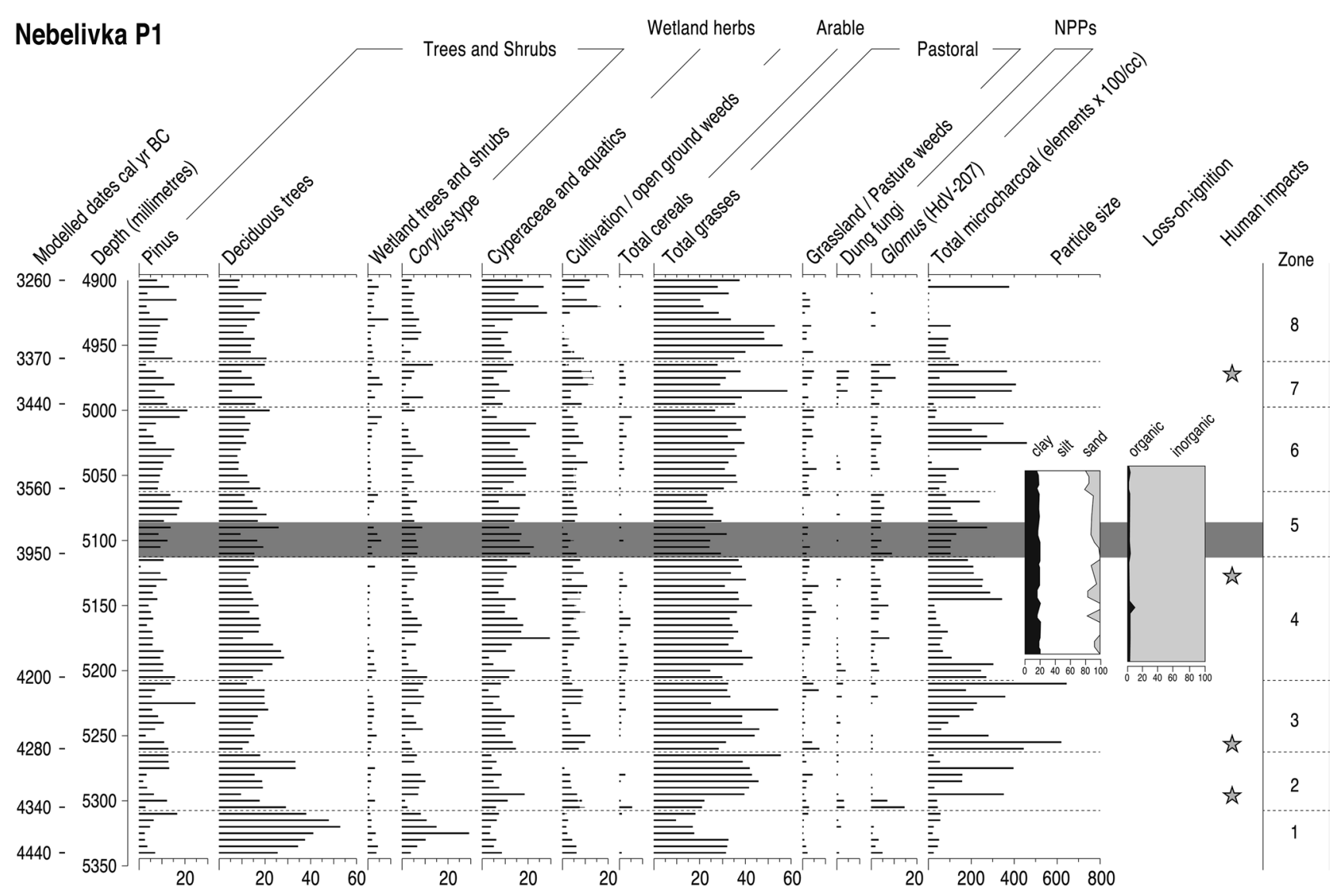

Fig. 5 Summary diagram (pollen, NPPs, charcoal, particle size, LoI and human impact). Key: stars—'impact events'; shaded band—period of megasite occupation

of the potential changes in pollen spectra following such a hiatus.

The overall conclusion from these sedimentological data is that there is no positive evidence in favour of a hiatus in core P1. The LoI data show no indications of any hiatus in sedimentation in the central part of the core, although there could be a hiatus, with the same depositional regimes above and below. Moreover, the absence of a buried A-horizon throughout the sediment core casts doubt on any depositional hiatus due to interruption in sedimentation. The overall consistency in Particle Size Analysis shows no indication of a particle size peak consistent with a hiatus due to an interruption of sedimentation or a higher-energy erosive episode.

Although we cannot rule out short hiatuses in the core, it is unlikely that there was an absence of sediment representing a continuous period of several hundred years but we cannot rule it out completely. However, if such a hiatus occurred during a maximalist occupation of Nebelivka, we should expect an ensuing legacy in the later pollen zones, which is not found. For example, it is important here to note the relatively steady curve of the arboreal: non-arboreal pollen ratio, where a lack of sharp changes does not support a depositional hiatus or a gradual forest regeneration after massive clearance during the site occupation. Similarly, there was no major change in the colour of the sediments with depth, contradicting an obvious depositional hiatus. Equally, the relationship between the frequencies of Cerealia and Glomus provide a picture of relative stability.

Another possible source of error is mixing of sediments in the alluvial basin through various taphonomic processes, such as bioturbation. This would cause a levelling out of any possible proxies for human impact peaks. However, such a process would also cause a blending of pollen grains to produce a sequence of similar vegetational signals. Since this is clearly not what occurs in any part of Zones 4-6, we can rule out the possibility of bioturbational mixing. Moreover, there was no evidence for ecorroded pollen grains.

There are several alternative explanations for the gradual erosion of sediments into the site of the core. The most probable scenario is developed on the basis of the inconsistent dates in the age-depth model. The inconsistent dates are very similar in age, suggesting a common source for the carbon in these samples, with the date approximately that of 
Table 1 Primary vegetation characteristics of Nebelivka pollen zones

\begin{tabular}{|c|c|c|c|}
\hline Pollen zone & Dates from age-depth model ( $2 \sigma$-ranges $)$ & Depth $(\mathrm{mm})$ & Primary characteristics \\
\hline 1 & $4880-4260$ to $4460-4170$ вс & $5,340-5,310$ & $\begin{array}{l}\text { Tilia, Ulmus, Quercus, Corylus and Poaceae dominant; arboreal pollen } \\
\text { (AP) rises from an initial low, led by Tilia (12.9 to } 37.2 \% \text { max.), Ulmus } \\
\text { (to } 14.8 \% \text { max.), Quercus ( } 8.9 \text { to } 19.0 \% \text { max.) and Corylus ( } 3.6 \text { to } \\
29.1 \% \text { max.); total Poaceae declines to an absolute minimum of } 9.6 \% \text {; } \\
\text { substantial Alnus; initial cultivation traces in the basal spectrum as } \\
\text { Cerealia along with the NPP Glomus (HdV-207); high levels of NPP } \\
\text { HdV } 18\end{array}$ \\
\hline
\end{tabular}

5,305- 5,265 Poaceae, Ulmus, Tilia and Quercus dominant; total Poaceae rises to a maximum of $55.4 \%$ as Tilia declines (to $4.4 \%$ min.) but Ulmus rises (to $24.9 \%$ max.); sporadic cultivation traces, including an initial spike of cereals (5.4\%) in tandem with high Cercophora (HdV-112) and Glomus.

5,260-5,210 Poaceae, Tilia, Ulmus and Quercus dominant; total Poaceae remains high (54.2\% max.), while AP declines, led by Ulmus (to $1 \%$ min.); Picea is present; traces of large (34-36 $\mu \mathrm{m})$ Poaceae occur; Typha angustifolia values rise; Nymphaea and Nuphar grains occur mostly in this zone; cultivation and Glomus consistently present in high values in the second half of this zone, including Triticum (diameter 39-43 $\mu \mathrm{m}$ ); high values $(10+\%)$ of Artemisia precede cultivation traces

5,205-5,115 Poaceae, Tilia, Quercus, Ulmus and Typha dominant; total Poaceae values from 35 to $40 \%$; large $(34-37 \mu \mathrm{m})$ Poaceae in significant quantities, up to $2.9 \%(5140 \mathrm{~mm})$; arboreal taxa like Tilia (c. 5\%) and Quercus (c.8\%) exhibit lower values; Ulmus values vary, initially rising (to $11.5 \%$ max.) and then declining (to $0.9 \%$ min.); high Typha angustifolia values, with presence of Potamogeton, Nymphaea and Nuphar; frequent cultivation traces include Hordeum and Triticum in the early part of the zone; mean total cereal pollen in this zone is $1.8 \%$, with a maximum of $4.8 \%$ $(5,160 \mathrm{~mm})$; high values ( $>8 \%)$ of Artemisia postdate main cultivation traces; moderately high values of Taraxacum and Plantago media; presence of NPP Glomus; sporadic Cercophora and Sporormiella (HdV113); the sordariaceous fungus Arnium (HdV-261) present in the middle of the zone; presence of two steppe plants - Dipsacus and Onobrychis

5,110-5,065 Poaceae, Tilia, Ulmus, Quercus, Cyperaceae and Asteraceae dominant; total Poaceae declines to a minimum of $22.3 \%$, while AP rises, with Quercus attaining a maximum of $14.5 \%$ and Tilia $8.5 \%$; substantial presence of Picea and Alnus; high Asteraceae values, with an absolute maximum of $10.8 \%$ at $5095 \mathrm{~mm}$; substantial presence of Plantago media; high Cyperaceae values, with a maximum of $19.8 \%$ at $5105 \mathrm{~mm}$; final presence of Potamogeton at $5080 \mathrm{~mm}$; cultivation traces and Glomus decline; sordariaceous fungus Arnium throughout this zone, more frequently than in Zone 4

5,060-5,000 Poaceae, Ulmus, Cyperaceae and Typha dominant; total Poaceae rises, with a maximum of $40.0 \%$ at $5,005 \mathrm{~mm}$, as AP declines; substantial presence of Alnus; high Cyperaceae values, with maximum of $13.2 \%$ at $5030 \mathrm{~mm}$; Typha angustifolia attains a high level of $18.8 \%$ at 5,010 mm; cultivation indicators and Glomus are moderate, with some Triticum differentiated; high peak in cereals $(5.1 \%)$ at $5,005 \mathrm{~mm}$

4,995-4,965 Poaceae, Tilia and Corylus dominant; total Poaceae declines (to 26.9\% min.), as Tilia rises (to $16.4 \%$ maximum) and sporadic rise in Corylus; Ulmus declines; substantial amounts of large (34-36 $\mu \mathrm{m})$ Poaceae, up to $1.3 \%(4,975 \mathrm{~mm})$; moderate representation of Convolvulus arvensis; Typha angustifolia declines; cultivation traces and Glomus decline, despite the rise in Cercophora and Sporormiella

4,960-4,900 Poaceae, Quercus, Cyperaceae, Typha, Chenopodiaceae dominant; Poaceae (c. 30\%) and Quercus (c. 8\%) values moderately high; Cyperaceae values are high, with an absolute maximum of $26 \%$ at $4,925 \mathrm{~mm}$; Typha angustifolia attains a maximum of $25.2 \%$ at $4,905 \mathrm{~mm}$; Chenopodiaceae attain an absolute maximum of $10.8 \%$ at $4,900 \mathrm{~mm}$ 
the colluvium at around 5,350 to $5,450 \mathrm{~mm}$. A widespread event generating organic carbon in the catchment and subsequently eroded at various times could explain this. Initial forest clearance for farming in the general Nebelivka area is a plausible explanation. These three indicators would suggest that, at a later date, part of the colluvial deposit, forming part of a mass movement of sediments (especially with rill and gulley erosion along a ca $30^{\circ}$ slope here) in a xerotic environment, remained perched on the foot slope above the alluvial accretion surface for a period of some centuries until later deposition into the drainage introduced old carbon at a depth of c. 4,900-5,150 mm. Three possible reasons include destabilisation of soils through human practices, climate deterioration or chernozem cryoturbation.

In the light of the absence of evidence for a sedimentational hiatus in core $1 \mathrm{~B}$, the improbability of bioturbational mixing of sediments and the availability of an alternative explanation for the out-of-sequence AMS dates, we conclude that there is a low probability of a hiatus during the period of the megasite occupation (3950-3750 вC) and that we can therefore consider the deposits in Zones 4, 5 and 6 as indeed related to megasite dwelling.

\section{Pre-megasite (Zones 1-3, fifth millennium Bc)}

\section{Vegetation history}

In the period which is certainly pre-megasite (4880-4260 BC to 4340-4070 BC), an initially open environment was followed by the expansion of a mixed Tilia-Ulmus-Quercus forest dominated by Tilia and then Ulmus. Prior to the pollen zones identified here, there was a period of intensive slope erosion (5,450-5,350 mm, 6830-4350 вс to 5240-4260 вС) (see above). A Tilia florescence in the earlier part of this period (middle part of Zone 1, 5,325 mm, 4460-4210 вС) is coeval with a rise of AP and may relate to forest succession (as in the chernozem areas at Milovice near Prague: Albert, personal observation). This hypothesis of a seral community is supported by co-variation of Corylus with Tilia, with high values of the shrub being expressed in Zone 1. The Ulmus-dominated forest characterizing the later part of the pre-megasite period would comprise a highly favourable environment for browsing animals and leaf foddering, supported by the high Artemisia values after a depth of 5,305 mm (Hejcmanová et al. 2014).

After the Cerealia spike at a depth of $5,305 \mathrm{~mm}$ (4460-4170 вC), the first continuous signs of cereal pollen of the Triticum, Hordeum and Cerealia types begin at $5,250 \mathrm{~mm}(4410-4100 \mathrm{BC})$; Cerealia pollen overall varies between 1 and $4.8 \%$, with high values in Zone 4 (Fig. 4, ESM 1 Fig. 5). This predates and extends into the megasite occupation. Thus there was a pre-megasite population practising agriculture in the Nebelivka region for which archaeological signatures have not yet been encountered. This may have been the same community which then developed the megasite, or a different group.

Also significant for local conditions near the coring site are coprophilous fungi like Cercophora and Sporormielladung indicators that also indicate a concentration of grazing animals (van Geel et al. 2003; Davis and Shafer 2006) (ESM 1 Fig. 6), although some circumspection is required (Wood and Wilmshurst 2012). These fungi are present in Zone 4 sediments from 5,180 to $5,120 \mathrm{~mm},(4320-4050$ вС to 4320-3580 вС), although isolates of Podospora (HdV 368), a fungus often associated with cattle dung, were present in Zone 4 and may have been related to occasional livestock grazing in the valley east of the Nebelivka promontory or the presence of wild animals.

\section{Sedimentology and palaeo-hydrology}

Mean sedimentation rates in the pre-megasite sediments are approximately $72 \mathrm{~mm}$ per century, with a reduction in Zone 4 to $42 \mathrm{~mm}$ per century. A half-millennium before the megasite occupation, the very high precipitation of carbonates, combined with low AP values, indicates drought and also rill and gulley erosion with partial devegetation of slopes lateral to the P1 core. Thus the high rates of sedimentation were caused by natural conditions, not human impacts. Glomus occurs in soil A-horizons as an indicator of erosion and accumulation in valley sediments lacking in situ soil formation. Glomus exhibits high values in Zone 1 basal spectra, thought to be the terminus of the drought, and then again during early cultivation in Zone 2 (ESM 1 Fig. 5). Later in this period, there was low net accumulation of fine sediments only. Importantly, this indicates a low-energy depositional environment and hence relatively low erosion and accumulation in the centuries before the megasite period, which is also an indication of low human impact with implications for climate and rainfall intensity.

Most wetland pollen types encountered in the sequence are classed as telmatic (fen and swamp) community, including Typha angustifolia and Cyperaceae. Typha occurs above $5,265 \mathrm{~mm}$ (4440-4120 вс) and increases before the megasite occupation, reflecting increasingly wet conditions from Zone 2 through to Zone 4 . The incidence of full-aquatics represents a higher water table, with Nuphar (yellow water-lily) inhabiting ponds as deep as $5 \mathrm{~m}$; Nymphaea or white waterlily has a similar indicative value. The presence of these water lilies exclusively in the later part of Zone 3 and all of Zone 4 indicates that maximum water tables were also achieved in the centuries before the megasite occupation, when the unnamed P1 drainage water table was at least one metre above the accretion surface. Significant water flow is also indicated by a lack of zygnemataceous algae (e.g. 
HdV-58 and HdV-313) typical of a still water environment (van Geel 2001) (ESM 1 Fig. 6).

\section{Microcharcoal and fire history}

According to fall-out characteristics (Blackford 2000), the highest values of the large elements with 126-175 $\mu \mathrm{m}$ long diameter are likely to be associated with fires near the drainage. With several exceptions, such fire phases predate the megasite, e.g. in Zone 3, and may have been short-lived. One event prior to the megasite occupation expresses an absolute maximum of microcharcoal at 5,210 mm (Fig. 5, ESM 1 Fig. 7). This maximum fire episode, dated $4350-4070 \mathrm{BC}$, is expressed by a concentration value of c. 65,000 elements/ $\mathrm{cm}^{3}$, and high values occur in adjacent samples also, indicating that the episode as a whole might have lasted more than a decade. With a view to correlation with cultural events, this may well reflect a pioneer farming event in the general Nebelivka area. The 5,210 mm microcharcoal event can also be related by size class to microcharcoal surface area (at focal plane) values, based upon an average encountered in a sub-sample of 100 fragments, so as to be directly comparable with the results at Crawford Lake (Clark and Royall 1995). The Crawford Lake study of an Iroquoian settlement in southern Ontario assessed charcoal influx in the same terms and is of particular interest also due to full excavation of an adjacent site of 15 th century AD date, which provides a reliable population estimate for a pre-industrial farming community responsible for charcoal influx.

In Nebelivka core P1, 26,000 microcharcoal elements of all size groups were deposited per annum in the sampled alluvial accretion surface at a depth of $5,210 \mathrm{~mm}$. When these elements are measured according to estimated $\mathrm{mm}^{2}$ per element, an influx rate of c. $40 \mathrm{~mm}^{2} / \mathrm{cm}^{2} /$ year of microcharcoal is calculated. This can be compared to the Crawford Lake findings, where a population of c. 600 resided for a period of c. 25 years C. AD 1440, and when an acute influx peak of c. $16 \mathrm{~mm}^{2} / \mathrm{cm}^{2} /$ year magnitude is registered. The Nebelivka fire event thus might reflect a major clearance process dating to well before the start of the megasite but enabling the earlier establishment of farming in the Nebelivka area. Furthermore, the event as such is not isolated, with many near-adjacent levels also producing high microcharcoal signals. Moreover, local valleys were relatively denuded by high relative sedimentation rates, as determined by the AMS dating of the pre-megasite layers of the core.

Significant aeolian fall-out would have occurred in relation to more distant sources (Blackford 2000), expressed as a high relative deposition of smaller microcharcoal. Such fall-out might help to distinguish agricultural exploitation of wooded areas close to the drainage from episodes of houseburning, as the megasite houses were only $250 \mathrm{~m}$ from the coring site. Proximity via airborne transport to the entire drainage would have been a key variable, as once microcharcoal was introduced into the fluvial system, the high kinetic energy of water flows would have transported all sizes of microcharcoal in a manner similar to pollen (cf. Brown et al. 2007). In conformity with this hypothesis, one abrupt rise of only the smaller microcharcoal particles (51-75 $\mu \mathrm{m}$ long diameter) begins at 5,145 mm (4330-3800 BC). The pattern of a maximum initial microcharcoal value followed by a gradual decline may be related to an initial burning followed by less frequent burning through time.

The only Early Trypillia site from which burning traces may have been carried into the Nebelivka Core P1 catchment is Phases A/BI of Stepkivka, a 15 ha site $20 \mathrm{~km}$ to the West (and therefore upwind of Nebelivka). It is improbable that the cultivation and/or house-burning practices of the three known Phase BI-II transition sites-the 150 ha site of Bagachivka, the 100 ha site of Vesely Kut and the 1 ha site of Horodyshche-could have impacted on the Nebelivka 1 core, since all three sites lie more than $50 \mathrm{~km}$ from Nebelivka (ESM 1 Fig. 8).

\section{Period of megasite occupation (Zones 4-6, early fourth millennium $B C$ )}

\section{Vegetation history}

The period associated with the occupation of the megasite exhibits continuous low AP but no absolute AP minimum (Fig. 4). The period begins with a decline in arboreal values in Zone 4, then a forest recovery, followed by signs of deforestation in Zone 6. Ulmus, Tilia and Quercus are dominant trees at different stages of this period. It is also of interest that rare pollen types like the sagebrush steppe indicator Dipsacus and the Euphorbiaceae were limited to the megasite period. However, the total spectrum characteristics of the megasite period, with high grasses and low forbs, do not indicate a steppe environment.

The reconstruction of cultivation history relies principally on the identification of cereal pollen types, particularly with a view to the limits of indicative values of weeds of cultivation (Fig. 4, ESM 1 Fig. 5). Although cereal indicators were less common in Zone 5, continuous cereal indicators in Zones 4 and 6 demonstrate that cultivation was important in the megasite periods (Fig. 4).With respect to specific cereal identifications, large Triticum grains $(45+\mu \mathrm{m}$ long diameter $)$ may also represent $T$. spelta as opposed to $T$. dicoccum, and potentially, very large Poaceae pollen (34-37 $\mu \mathrm{m}$ long diameter) may also reflect cultivation of early Hordeum and Triticum varieties (Albert and Innes 2015). With respect to wild grasses, the rise and fall of the smaller Poaceae is negatively correlated with the relative values of larger grains. There were insufficient large grass grains that could be confused 
with cereal pollen as to make under-representation of the latter an issue.

The farming phase defined by the continuous cereal curve begins before the megasite occupation and ends after the occupation. The cereal curve contains high peaks of total cereal pollen ( $>4 \%$ at 5,180 and $5,160 \mathrm{~mm}, 4320-4050 \mathrm{BC}$ and $4330-3980 \mathrm{BC} ;>5 \%$ at $5,005 \mathrm{~mm}$, dating to $3750-3080$ вC). At counts of 250 to 500 total land pollen grains here, this variation of total cereals is outside the $95 \%$ confidence interval, indicating that cultivation in this period was variable without any discernible trajectory of increasing intensity. No expansion or intensification of local farming is detectable and the observed variability is probably related to proximity factors, with mean total cereal pollen values remaining lower than $2 \%$. This is a moderate value range for an alluvial site in a chernozem basin near the arable fields, where cereal pollen is not reduced by the predominant water transport. It is much lower than in similar pollen taphonomic situations in, for example, the lowland Czech Republic (see above; Albert and Pokorný 2012), suggesting that medium-term fallowing in the order of four to five years is estimated on this basis, producing a limited development of a distinctive annual weed flora.

The levels coeval with the megasite occupation show low levels of coprophilous fungi (Cercophora and Sporormiella), with little signs of a concentration of grazing animals in the catchment (van Geel 1986, 2001; van Geel et al. 2003). Offsite sanitary arrangements hypothesized for the thousands of megasite dwellers would also have influenced the occurrence of such vegetation. This conclusion is supported by the occurrence in Zone 5 of plants mildly toxic to grazing animals, such as Convolvulus arvensis, which the animals would have avoided. The significance of pastoral land use at Nebelivka is also difficult to define according to other pollen data, due to ambiguous indicative values of ruderal species such as Plantago media, that may reflect trampling rather than grazing (ESM 1 Fig. 5) (Sagar and Harper 1964).

Finally, the changes in the frequencies of decomposers (NPPs) may be related more to local conditions, in which several trees may have fallen and lay rotting near the coring site, than to the burning and eventual rotting of over 1,400 Trypillian houses of mean size $12.7 \mathrm{~m}$ in length and $4.8 \mathrm{~m}$ in width (Müller and Videiko 2016) and 23 Assembly Houses (of larger size) which were built at the megasite (Chapman and Gaydarska 2016). It is interesting that most identified fungi of the types Arnium and Arnium imitans (HdV-262), which thrive in rotting wood as well as vegetable crops (van Geel et al. 2003), occurred during the megasite occupation, with a few instances in Zone 3 (ESM 1 Fig. 6).

\section{Sedimentology and palaeo-hydrology}

It is noticeable that mean sedimentation rates for silty clays from 5205 to $4995 \mathrm{~mm}$ (Zones 4-6, 4340-4070 вС to $3720-3050$ ) varied from 13 to $50 \mathrm{~mm}$ per century, with the lowest rate in Zone 5. Concerning NPP data, Glomus exhibited highest values in Zones 4 to 6 (ESM 1 Fig. 6), indicating that mean sediment rates from soil erosion were higher than before the megasite occupation (Fig. 5, ESM 1 Fig. 6). This inference is supported by an almost continuous accumulation of significant Glomus. Full-aquatic pollen types disappeared in the period of the megasite occupation but Potamogeton, which inhabits shallower waters, occurs only in Zones 4 and 5. Water tables may have been 50 to $100 \mathrm{~cm}$ lower in the megasite period than before.

\section{Microcharcoal and fire history}

The charcoal peaks at the time of megasite occupation do not correlate with the cereal peaks in the megasite occupation period (cf. Fig. 5, ESM 1 Fig. 7), suggesting either that the charcoal is more closely related to domestic fires or houseburning than to deforestation by fire or that the fields were too far from the coring site to make a difference. Trypillia sites contemporary with the Nebelivka occupation lay between $6.5 \mathrm{~km}$ (Ostrivets) and $15 \mathrm{~km}$ (Sushkivka) to the west of Nebelivka. It seems improbable that traces of their agricultural practices would have affected the Nebelivka 1 core, which reveals no micro-charcoal peak comparable to the major fire event at the depth of 5,210 $\mathrm{mm}$.

\section{Post-megasite (Zones 7-8, mid-late fourth millenium $\mathrm{BC}$ )}

\section{Vegetation history}

In Zone 7, there is a further increase in Tilia, with minor rises in Corylus, whereas in Zone 8, forest composition significantly changed to a gradual dominance of Quercus, perhaps related to cooler climatic conditions (Harper 2016). Cultivation indicators continue as in Zone 6, with high values for large Poaceae in Zone 7 (possibly indicating $\mathrm{H}$. vulgare or T. monococcum) and Chenopodiaceae in Zone 8. Zone 7 continued to show high levels of coprophilous fungi (Cercophora and Sporormiella), indicating the presence of grazing animals in the catchment and reflecting a continued pastoral use of the landscape.

\section{Sedimentology and palaeo-hydrology}

The high Glomus values in Zone 7, matching those in Zones $4-6$, suggest continued erosion into the alluvial basin. A terminal increase in telmatics may indicate even shallower 
water levels in the valley in the post-megasite period, as well as the establishment of marsh or swamp conditions.

\section{Microcharcoal}

Microcharcoal influx in the post-megasite period was generally well correlated with further agricultural activity, except for one high-influx event at 4,905 mm (3570-2970 вс) which may reflect a natural fire (Fig. 5, ESM 1 Fig. 7) or the inwash of older, charcoal-rich sediment.

\section{Overall assessment of ecological impact}

The general assessment of each of the five kinds of human impacts we expected to find in the Nebelivka P1 diagramcereals, charcoal, agro-pastoral indicators, erosion and hydrology - is based upon a tabulation of the key depths at which changes can be noted (Fig. 3; ESM 1 Table 4, ESM 2).

Forest cover was highest in the early Zones, reaching peaks of 55\% total land pollen in Zone 1 and $45 \%$ in Zones 2 and 3 but rarely more than $30 \%$ in Zone 8 . There is thus a gradual, cumulative decline in forest cover over the central part of the core, with cycles of forest clearance and re-afforestation in each Zone from Zone 3 to Zone 8-viz., before, during and after the megasite occupation, which begins with a re-afforestation peak at $5,230 \mathrm{~mm}$ followed by an abrupt clearance phase. Minor episodes of elm decline are dated to the megasite period but all were reversed within a period of decades. Both episodes were of a magnitude found before and after the megasite occupation. In the entire diagram there is no single forest clearance event indicating a massive phase of building and/or burning.

The micro-charcoal sequence shows a series of peaks in either two or all three size ranges but nothing on the scale of the major 5,210 $\mathrm{mm}$ fire event in late Zone 3. Although cereal indicators pre-date this event, it is likely that it represented a significant opening-up of the Nebelivka landscape for agro-pastoral activities through widespread burning of the primary forest. Age-depth modelling puts this fire event at least 100 years before the foundation of the megasite, although it could have been coeval with the start of dwelling. Thereafter, the periodicity of minor micro-charcoal peaks before, during and after the megasite period, rarely matched those of Cerealia pollen, suggesting the cause lay in houseburning rather than burning of primary forest.

The age-depth model suggests a long duration of cultivation, at least 500 years and probably 900 years from initial cultivation in Zone 2 to a maximum in Zone $6(5.1 \%$ cereals). This time-span is much longer than the modelled occupation period of the megasite. After an early Zone 3 spike in Cerealia pollen at $5,305 \mathrm{~mm}$, a continuous curve of Triticum, Hordeum and Cerealia pollen lasted well into the megasite period, when especially large Triticum grains suggest $T$. spelta rather than $T$. dicoccum-a finding not supported by the archaeo-botanical results from Nebelivka (Pashkevych 2014). The sequence of cereal pollen findings indicates variable levels of cultivation rather than increased agricultural intensification, with the poverty of definitive annual weed flora suggestive of a four- to five-year fallowing system. Cereal indicators continue in the post-megasite period but show a decline in Zone 8. NPP pastoral indicators began to be important in the megasite period (Zone 4) and increased in Zones 5-6, although signals for intensified pastoralism are contradictory. Further increases in Zones 7 and 8 indicate the likelihood of greater reliance on pastoralism in the post-megasite period.

Sedimentation from A-horizon sources is strongly indicated by very high levels of ascospores of Glomus - a native to biologically active soils-in many cases above 5\% TLP. This NPP type is present throughout the pollen sequence albeit in much lower values or absent in Zone 8. Its appearance from Zone 2 onwards was often correlated with agricultural indicators. The highest Glomus values were found in all three phases coeval with megasite dwelling, suggesting that moderate land erosion was a long-term effect of megasite dwelling.

Our indicators for palaeo-hydrology reveal a striking pattern of increasing water depth and flow through the pre-megasite Zones 2-3 and the earlier part of the megasite, with water depth estimated at $1 \mathrm{~m}$ above the coring surface. The disappearance of full-aquatic plants in Zones 5-6, and their replacement by shallow-water species, shows a fall in water quality and a drop in the water table. An even lower water table is proposed for the postmegasite period. The megasite demand for drinking water, water for the construction of houses and animal use of rivers and streams must have placed a strain on the relatively small water resources of the Nebelivka area, even in periods of increased rainfall (Cordova and Lehmann 2005).

We have identified four 'impact events' where three of the five classes of impact information changed at the same depth (Figs. $5 \& 6$ ). Two of the four 'impact events' occurred before the occupation of the megasite, in Zones $2(5,300 \mathrm{~mm})$ and the Zone $2 / 3$ transition $(5,265 \mathrm{~mm})$. The third impact event, in Zone $4(5,135 \mathrm{~mm})$ is marked by a combination of peaks in cereals, weeds of cultivation and pasture weeds. The fourth 'impact event', in Zone 7 $(4,980-4,975 \mathrm{~mm})$ is defined by a wide-ranging combination of peaks in cereals, weeds of cultivation, microcharcoal, dung indicators and Glomus as well as aquatics, suggesting continued mixed farming in the post-megasite period. One significant conclusion is that the impact events are by no means limited to, or indeed correlated with, the megasite dwelling period, reinforcing the suggestion that there were both pre-megasite and post-megasite 


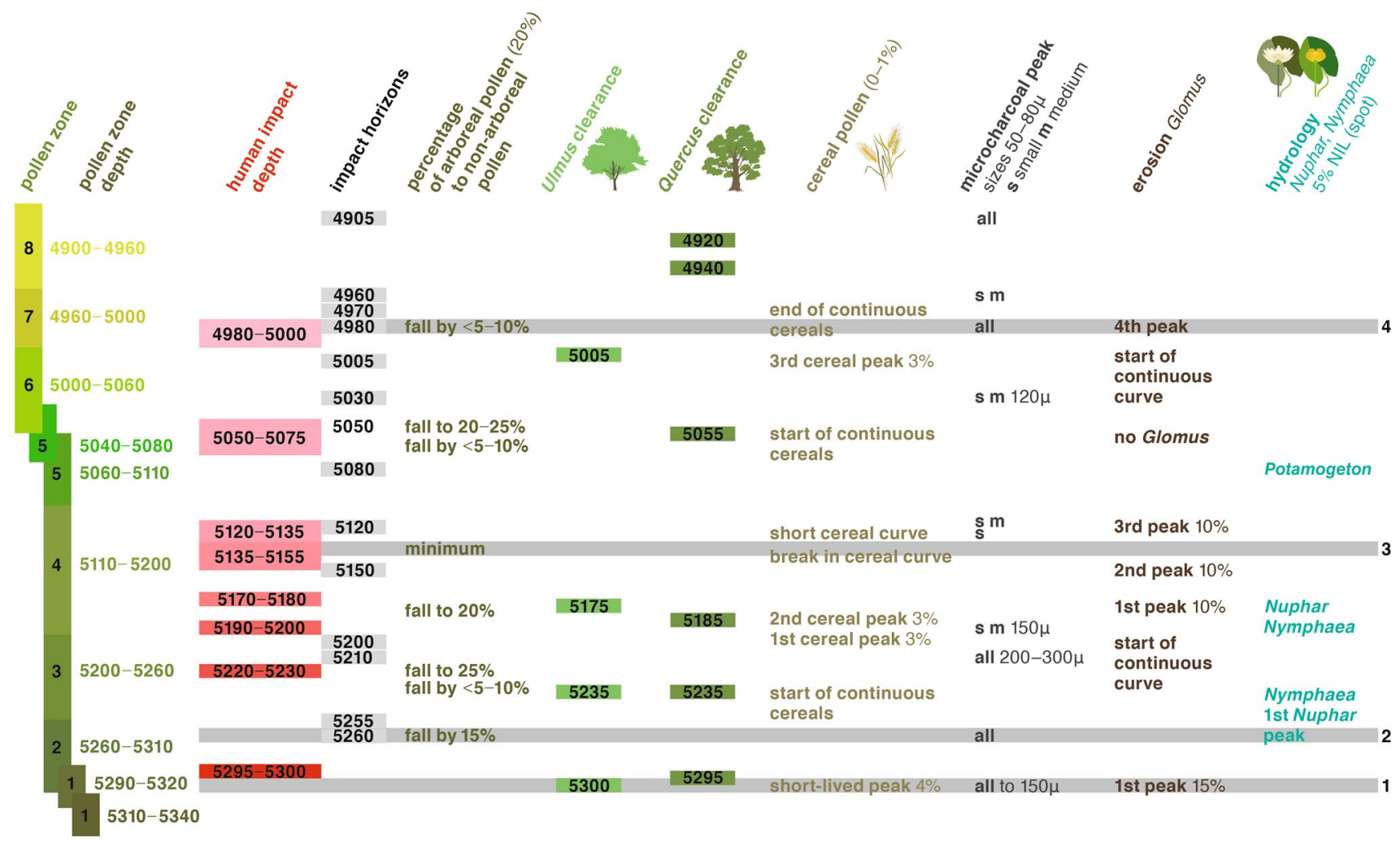

Fig. 6 Summary of human impacts (C. Unwin). Key—horizontal bars denote 'impact events'

settlements in the Nebelivka area which have not yet been discovered during fieldwalking.

A second point is the lack of synchronisation between the micro-charcoal peaks, of which 10 were found in the core, with any of the impact events. Only three microcharcoal peaks were found in layers coeval with the megasite occupation and, of these three, only the $4,980 \mathrm{~mm}$ peak in Zone 7 was found in all three microcharcoal sizes. That these peaks might represent times of inwash of older charcoal from the catchment, rather than contemporaneous burning, must be considered.

Can the imprecise dating of the layers of the P1 pollen core with respect to the megasite occupation permit a different dating of the megasite relative to the P1 sediment core? Is it possible that the wide $95 \%$ probability margins of the $\mathrm{P} 1$ core can sustain a dating of the layers in which the major 5,210 $\mathrm{mm}$ fire event in Zone 3 can date the start of the megasite occupation? After all, this hypothesis would partially solve the problem of the non-existence of pre-megasite settlement in the Nebelivka area by assigning the initiation of a 'cultural steppe' to the pioneer settlers of the megasite. This would mean the coincidence of the fire event with the highest-quality water, a forest clearance, the start of the continuous cereal and Glomus curves and high NPP indicators for grazing animals. However, the modelled $95 \%$ confidence limits of the date of that depth (4350-4070 BC) mean that there is a very low statistical possibility for the equation of the major 5,210 $\mathrm{mm}$ fire event to the start of the megasite.

Indeed, following this comparison of two chronological 'solutions' to the imprecision of the age-depth model, it is important to underline what is perhaps the most important conclusion of our investigations-namely that there is no sign of major human impact at any point in the P1 sequence. The well-preserved pollen, charcoal and NPPs permit an assessment of ecological impacts and there is no concentrated impact of all five forms of evidence anywhere in the sequence. Accepting the age-depth model, what we find are increases in erosion rates and a decline in water quality during the megasite occupation. Given the variations in population numbers even between the various 'minimalist' models (currently modelled at $1,500-4,000$ ), not to mention the maximalist estimates of $10,000-46,000$ people, the increase in land erosion rates and the decline in water quality in what is, after all, a small hydrological network, come as no surprise. What is more significant is the lack of sustained high cereal values and high pastoral indicators, as much as the absence of spikes in the micro-charcoal curve, especially at the end of the megasite occupation. It is these absences which suggest that the minimalist models are far more likely to be correct and that it is time to consider them seriously 
as the ecological impact required by maximalist models is not observed.

The second most important conclusion stemming from the acceptance of the age-depth model concerns the high probability that there were indeed mixed farmers living in the Nebelivka area both before the settling of the megasite, and after its abandonment, even though their artifactual footprint has not yet been found. There is ceramic evidence for an earlier (Phase A) settlement only $20 \mathrm{~km}$ from Nebelivka. Intriguingly, the persistence and strength of pre- and post-megasite agro-pastoral indicators were comparable to those found in the megasite period. However, there is no support from the age-depth model for the dating of the major $5,210 \mathrm{~mm}$ fire event to the pre-megasite period. Moreover, nothing on the same scale as the $5,210 \mathrm{~mm}$ event has been detected in the micro-charcoal record for the megasite occupation (3950-3750 вс). It seems highly likely that this pioneer clearance event in the late fifth millennium $\mathrm{BC}$ increased the attractions of the Nebelivka promontory for subsequent dwelling (cf. molluscan evidence for a cleared, grazed-grass promontory: Miller 2019, https://doi.org/10.5284/1047597, Section 3.5.4).

\section{Extended discussion}

We have not yet been able to reach resolution in the debate over the sedimentation between the Hiatus Hypothesis and the Continuous Sedimentation Hypothesis. Although the preponderance of the evidence supports continuous sedimentation, we cannot rule out a depositional hiatus, but we have no evidence for the date of that possible occurrence. If one argues that the change in sedimentation rate around $5,100 \mathrm{~mm}$ is an indicator of a hiatus, then its position in the period 4270-3510 BC (the 95\% range for that depth) means that it could be contemporary with the megasite occupation. However, it is only the change in sedimentation rate that suggest a hiatus and none of the other evidence corroborates it. The most probable conclusion is continuous, variable deposition at the P1 coring site. There are no changes of sufficient magnitude in the pollen frequencies in the central part of the P1 diagram to suggest climatic fluctuations in the late fifth to early fourth millennia BC (contra Harper 2017; Shumilovskikh et al. 2017).

Bayesian modelling of the 82 AMS dates for the Nebelivka megasite indicates the most probable duration of occupation as 150-200 years, within the date range of 3950-3750 BC. Although each $5 \mathrm{~mm}$ sample from the central core section covered half to a few decades, there are only eight dates in stratigraphic order in the core, with the remaining three outliers reducing the precision of the age-depth Bayesian model. The identical values of the outlier dates suggest redeposition of old sediments originally deposited during an episode of colluviation several centuries before the megasite period. The most probable correlation of the P1 core with the megasite occupation is that Zones 1-3 predate the premegasite period, the megasite occupation could have been during any or all of Zones 4-6 and Zones 7 and 8 date to the post-megasite period.

The most important result of this investigation concerns a surprisingly modest human impact in the megasite period, with only land erosion rates and water quality significantly different from before or after the megasite period. The second, and equally surprising result was the evidence for non-intensive farming and a limited 'cultural steppe' development in interfluves before and after the megasite was occupied. The opening-up of the Nebelivka landscape and its high water quality may well have increased the attractions of the Nebelivka area to settlers at the megasite.

In all three major periods (pre- and post-megasite and during the megasite), the paucity of annual weed floras suggests extensive arable agriculture based upon a relatively long fallowing interval and serviced also by animal transport. The increase in population consequent upon megasite dwelling would suggest the likelihood of changes in the arable regime, whether more intensive or more extensive. However, there is little evidence for agricultural intensification, either in terms of plough technology (animal pathologies, plough models) or selection of higher-yield cereals. These findings support the interpretation of a modest human impact on the megasite landscape.

The support of a large population of the order of several thousand people at Nebelivka is possible, then, only under conditions of a very extensive agriculture. Recent modelling of Neolithic agriculture (Bogaard et al. 2013) has shown that most mature Neolithic agriculture was developed through extensification rather than intensification. In the Trypillia case, an agriculture that is essentially unmodified since the Neolithic is involved (Pashkevych 2012). Should populations in the order of 5,000 be resident permanently, this would involve a chernozem land area in the order of at least 1,000 ha over a radius of several $\mathrm{km}$ (Gaydarska 2003). Significantly, this would also involve major labour inputs in terms of cart or sledge transport over several kilometres. However, three seasons' field-walking (2012-2014) of c. $50 \%$ of the arable fields within a $5 \mathrm{~km}$ radius of the Nebelivka megasite have detected no more than a single Trypillian sherd (ESM 1 Fig. 9), although sites of other periods are recorded, while the nearest previously recorded Trypillian site was $6.5 \mathrm{~km}$ away. This almost total absence of discard undermines the highly extensive agriculture model. It also means that we cannot talk meaningfully about a 'rural hinterland' for the megasite of Nebelivka. It is highly probable that a very high proportion of people in the Nebelivka area were resident in the megasite itself, practising low-efficiency agriculture, as Pashkevitch $(2005,2012)$ has long maintained. The increased significance of the pastoralist component 
in megasite subsistence, as argued by Videiko (2013), is not attested in the core but increases in the percentage of domestic animals to over $90 \%$ suggest greater household control over stock and feasting than in pre-megasite settlements (Orton et al. 2019, https://doi.org/10.5284/1047597. Section 3.6.1).

The recent attempt to model Trypillia-Cucuteni mixed farming, using an impressively high number of parameters (Shukurov et al. 2015) reaches the conclusion that any sites larger than 40 ha, with 1,200 inhabitants, would have reached the logistical limits of available land use, with its requirement of a $10 \mathrm{~km}$ radius of land for all major subsistence practices, without the introduction of dietary (dairying) or technological (ards) innovations. However, the megasites are between four and eight times the size of the 40 ha logistical maximum; indeed, Shukurov et al. (2015, p 277) resist the challenge of modelling megasite subsistence on the grounds that these sites were rare and each was unique. But medium-sized Trypillia sites were not so rare. We are left with two possible conclusions: either $25-33 \%$ of Trypillia sites with size data (those larger than 30-60 ha) would have become unsustainable on the Shukurov model, or such a high proportion of unsustainable medium-sized to large Trypillia sites means that the model is incorrect through the gross under-estimation of plant and animal productivity. Assuming that the model is indeed correct, the former answer evidently provides strong support for the "minimalist' position of lower population densities.

The lack of evidence for both intensification and extensification of agriculture, as much as the tenets of the Shukurov model, means that there was a limit on the number of Nebelivka residents relying on local subsistence products. Several authors have characterised megasites in what may be described overall as a 'maximalist' manner (Shmagliy 1980; Markevitch 1981; Kruts 1990, to name but a few); their interpretations share the common elements of high populations and long-term permanent settlement. Our results invariably highlight the alternatives to the 'maximalist' model of megasite dwelling, all of which focus on a smaller number of people who lived all-year, full-time, at the megasite together with a larger number of visitors. In these models, the people resided at the megasite for several years or a decade (the Distributed Governance model: Gaydarska in press b) or came to Nebelivka as visitors either to a seasonal assembly (the Assembly model: Nebbia et al. 2018) or as pilgrims to a pilgrimage centre for short periods during the snow-free season of six to seven months (the Pilgrimage model: Chapman and Gaydarska in press). Each of these models posits a combination of a far lower local production of cereals and the provision of key resources by the visitors, also involving a major logistical and transport effort. The limitations on the shape of these models were set by four parameters: the number of houses on site, the number of houses fully or partially burnt, the length of the megasite occupation and the proportion of coeval houses. While one version of the Assembly Model has been rejected, it has, nevertheless, been possible to model seasonal or small-scale settlement in each of the alternative models. Further research is necessary to refine the alternative minimalist' models of megasite dwelling at Nebelivka.

\section{Conclusions}

Palynology and allied sediment studies at the Nebelivka megasite have enabled the reconstruction of environmental changes in close proximity to this large site in central Ukraine around 6,000 years ago. In the case of the Nebelivka megasite in the Trypillian BII phase, the reconstruction of a moderate impact according to palynology and local sedimentology is in some ways surprising, and indicates that the trajectory towards agglomeration of settlement populations here is not related to agricultural intensification, although natural hydrological conditions are favourable to such an agglomeration in Phase BII. Premegasite environmental conditions show the creation of a small-scale 'cultural steppe' in the process of extensive farming in the Nebelivka area.

The Nebelivka core is the first sediment core ever to have been recovered so close to a Trypillia megasite with detailed pollen, Loss on Ignition, particle size analysis and microcharcoal analyses. It is also the first core from outside major valleys, such as the Southern Bug or the Dnieper, to provide a vegetation history of the loesslands of South Central Ukraine. Although some of the AMS determinations date sediments secondarily re-deposited from the valley slopes, there are sufficient dates in stratigraphic order for a broad alignment of the sediments with the well-dated Nebelivka megasite (3950-3750 BC). It is important to differentiate between precision and resolution in the dating - between the high resolution of the sampling interval and the low precision of the dating.

The moderate human impact recorded during the megasite occupation, combined with the stronger evidence for fires, cereal and weeds-of-cultivation peaks both before and after this occupation, come as a considerable surprise to Trypillia specialists and those interested in early urbanism in Europe. It should be emphasized that the absence of a major ecological impact at any point in the sequence means that, despite dating issues, the results on human impacts are reliable.

Three possible scenarios should be considered in the light of such findings. The first and most obvious implication of these results is that the 'maximalist' scenario of truly massive populations in Trypillia megasitesranging from 12,000 to 46,000 people living coevally at 
Majdanetske-must be rejected. In the second scenario, Pashkevitch's (2005) traditional interpretation of Trypillia megasite agricultural practices as extensive, inefficient, low-yield arable farming with a modest level of pastoralism, implied a large area of cultivated land reaching $10 \mathrm{~km}$ or more from the megasite and the necessity for wheeled vehicles and animal traction. However, this scenario is potentially fatally threatened by the lack of off-site discard anywhere within the Nebelivka micro-region. The third scenario requires us to face up to the possibility of smaller-scale and/or seasonal agglomerations at Trypillia megasites rather than long-term, massive, permanent populations. This challenge requires a new approach to Trypillia taphonomy, house-burning and object deposition. The moderate human impact on the Nebelivka environment and the dispersed nature of burning episodes would support the third scenario of smaller-scale and/or less permanent agglomerations more than the maximalist scenario or the second scenario of extensive agriculture and pastoralism. Although initial modelling of three alternative 'minimalist' scenarios has been successful, we are thus still some way from reaching a conclusion on the basic settlement and subsistence characteristics of these massive settlements.

Acknowledgements This research was supported by AHRC Research Grant No. AH/I025867/1, National Geographic Society Grant No. 2012/211 and a British Academy Small Research Grant, to all of whom we are most grateful. We are also grateful to the Durham University Departments of Archaeology and Geography, which supported the research at critical times. We thank the coring team members Joe Roe and Sean Hamer for their efforts and muscle. Finally, we acknowledge the helpful comments of Wiebke Kirleis and Galina Pashkevych on earlier drafts of the article.

Open Access This article is distributed under the terms of the Creative Commons Attribution 4.0 International License (http://creativeco mmons.org/licenses/by/4.0/), which permits unrestricted use, distribution, and reproduction in any medium, provided you give appropriate credit to the original author(s) and the source, provide a link to the Creative Commons license, and indicate if changes were made.

\section{References}

Abraham V, Kozáková R (2012) Relative pollen productivity estimates in the modern agricultural landscape of Central Bohemia (Czech Republic). Rev Palaeobot Palynol 179:1-12

Albert BM (2007) Climate, fire, and land-use history in the oak-pinehickory forests of Northeast Texas during the past 3500 years. Castanea 72:81-90

Albert BM (2011) Acidification and pine expansion in East Texas according to pollen evidence from dual cores in alluvium. Castanea 76:164-177

Albert BM, Innes JB (2015) Multi-profile fine-resolution palynological and micro-charcoal analyses at Esklets, North York Moors,
UK, with special reference to the Mesolithic-Neolithic transition. Veget Hist Archaeobot 24:357-375

Albert BM, Pokorný P (2012) Pollen taphonomy at Vranský potok versus Zahájí alluvial pollen sites: methodological implications for prehistoric cultural landscape reconstruction in the Peruc Sandstone area, Czech Republic. Interdiscip Archaeol 3:27-44

Andersen ST (1979) Identification of wild grass and cereal pollen. Dan Geol Unders. Arbog 1978:69-92

Behre K-E, Kučan D (1986) Die Reflektion archäologisch bekannter Siedlungen in Pollendiagrammen verschiedener Entfernung - Beispiele aus der Siedlungskammer Flögeln, Nordwestdeutschland. In: Behre K-E (ed) Anthropogenic indicators in pollen diagrams. Balkema, Amsterdam, pp 95-114

Blackford JJ (2000) Charcoal fragments in surface samples following a fire and the implications for interpretation of subfossil charcoal data. Palaeogeogr Palaeoclimatol Palaeoecol 164:33-42

Bogaard A et al (2013) Crop manuring and intensive land management by Europe's first farmers. Proc Natl Acad Sci USA 110:12,589-12,594

Bradshaw RHW, Webb T III (1985) Relationship between contemporary pollen and vegetation data from Wisconsin and Michigan, USA. Ecology 66:721-737

Bradshaw EG, Rasmussen P, Odgaard BV (2005) Mid- to late-Holocene land-use change and lake development at Dallund S0, Denmark: synthesis of multiproxy data, linking land and lake. Holocene 15:1,152-1,162

Bronk RC (2009) Dealing with outliers and offsets in radiocarbon dating. Radiocarbon 51:1,023-1,045

Bronk Ramsey C (2008) Deposition models for chronological records. Quat Sci Rev 27:42-60

Bronk Ramsey C (2009) Bayesian analysis of radiocarbon dates. Radiocarbon 51:337-360

Bronk Ramsey C, Lee S (2013) Recent and planned developments of the program OxCal. Radiocarbon 55:720-730

Brown AG, Carpenter RG, Walling DE (2007) Monitoring fluvial pollen transport, its relationship to catchment vegetation and implications for palaeoenvironmental studies. Rev Palaeobot Palynol 147:60-76

Chapman J (2015) Burn or bury? Mortuary alternatives in the Neolithic and Chalcolithic of Central and Eastern Europe. In: Diachenko A, Menotti F, Ryzhov S, Bunyatyan K, Kadrow S (eds) The Cucuteni-Trypillia cultural complex and its neighbours. Essays in memory of Vlodomyr Kruts. Astrolyabia, Lviv, pp 259-278

Chapman J, Gaydarska B (2016) Low-density urbanism: the case of the Trypillia group of Ukraine. In: Fernández-Götz M, Krausse D (eds) Eurasia at the Dawn of History: urbanisation and social change. Cambridge University Press, Cambridge, pp 81-105

Chapman J, Gaydarska B (in press) The pilgrimage model for Trypillia megasites: the case of Nebelivka, Ukraine. In: Stîrbu V, Comşa A (eds) To appear in C. Schuster Festschrift. Bucureşti

Chapman J, Videiko M (2011) The Tripillia culture megasite near Nebelivka: summer 2009 season. Praehistorica 29:79-94

Chapman J, Videiko MYu, Gaydarska B et al (2014a) The planning of the earliest European proto-towns: a new geophysical plan of the Trypillia mega-site of Nebelivka, Kirovograd Domain, Ukraine. Antiquity Project Gallery 88(339)

Chapman J, Videiko MYu, Hale D et al (2014b) The second phase of the Trypillia megasite methodological revolution: a new research agenda. Eur J Archaeol 17:369-406

Clark JS, Royall PD (1995) Transformation of a northern hardwood forest by aboriginal (Iroquois) fire: charcoal evidence from Crawford Lake, Ontario, Canada. Holocene 5:1-9

Cordova CE, Lehmann PH (2005) Holocene environmental change in southwestern Crimea (Ukraine) in pollen and soil records. Holocene 15:263-277 
Davis O, Shafer DS (2006) Sporormiella fungal spores, a palynological means of detecting herbivore density. Palaeogeogr Palaeoclimatol Palaeoecol 237:40-50

Eckmeier E, Gerlach R, Gehrt E, Schmidt MWI (2007) Pedogenesis of chernozems in central Europe-a review. Geoderma 139:288-299

Fægri K, Kalland PE, Krzywinski K (1989) Textbook of pollen analysis. Wiley, Chichester

Gaydarska B (2003) Application of GIS in settlement archaeology: an integrated approach to prehistoric subsistence strategies. In: Korvin-Piotrovsky AG, Kruts VA, Ryzhov SM (eds) Tripolian settlement-giants. The international symposium materials. Korvin Press, Kiev, pp 212-216

Gaydarska B (ed) (in press a) Early urbanism in Europe: the case of the Trypillia mega-sites. De Gruyter, Dordrecht

Gaydarska B (in press b) Fragmenting Trypillian megasites: a bottomup approach. In: Fernández-Götz M, Chevral T (eds) Power from below. Cambridge University Press, Cambridge

Gerasimenko NP (1997) Environmental and climatic changes between 3 and $5 \mathrm{ka}$ вP in southeastern Ukraine. In: Dalfes HN, Kukla G, Weiss $\mathrm{H}$ (eds) Third millennium BC climate change and old world collapse. Springer, Berlin, pp 371-399

Grimm EC (1987) CONISS: a FORTRAN 77 program for stratigraphically constrained cluster analysis by the method of incremental sum of squares. Comput Geosci 13:13-35

Harper J (2016) Climate, migration and cities on the Old European periphery: a spatial-demographic approach to understanding the Tripolye giant-settlements. PhD, SUNY-Buffalo. Ann Arbor, MI: Proquest

Harper J (2017) Demography and climate in Late Eneolithic Ukraine, Moldova and Romania: multiproxy evidence and pollen-based regional corroboration. J Archaeol Sci Rep 23:973-982

Hejcman M, Hejcmanová P, Pavlů V, Beneš J (2013) Origin and history of grasslands in Central Europe - a review. Grass Forage Sci 68:345-363

Hejcmanová P, Stejskalová M, Hejcman M (2014) Forage quality of leaf-fodder from the main broad-leaved woody species and its possible consequences for the Holocene development of forest vegetation in Central Europe. Veget Hist Archaeobot 23:607-613

Jacobson GL, Bradshaw RHW (1981) The selection of sites for paleovegetational studies. Quat Res 16:80-96

Joly C, Barillé L, Barreau M, Mancheron A, Visset L (2007) Grain and annulus diameter as criteria for distinguishing pollen grains of cereals from wild grasses. Rev Palaeobot Palynol 146:221-233

Korvin-Piotrovskiy AG, Chabaniuk V, Shatilo L (2012) Tripolian house construction: conceptions and experiments. In: Menotti F, Korvin-Piotrovskiy AG (eds) The Tripolye culture giant-settlements in Ukraine: formation, development and decline. Oxbow Books, Oxford, pp 210-229

Kremenetski CV (1995) Holocene vegetation and climate history of southwestern Ukraine. Rev Palaeobot Palynol 85:289-301

Kremenetski CV (2003) Steppe and forest-steppe belt of Eurasia: Holocene environmental history. In: Renfrew C, Levine M (eds) Prehistoric steppe adaptation and the horse. MacDonald Archaeological Monographs, Cambridge, pp 11-27

Kremenetski CV, Chichagova OA, Shishlina NI (1999) Palaeoecological evidence for Holocene vegetation, climate and land-use change in the low Don basin and Kalmuk area, southern Russia. Veget Hist Archaeobot 8:233-246

Kruts V (1990) The layout of the settlement near Talianki village and some aspects of Tripolye house building. In: Zbenovich V (ed) Раннеземледельческиепоселения-гиганты трипольской культуры на Украине: Тез. докл. Іполевогосеминара. Тальянки, pp 43-47

Liverani M (2006) Uruk: la prima città (English translation). Equinox, London
Markevitch VI (1981) Pozdnetripolskie plemena Severnoj Moldavii. Shtiintsa, Chisineu

Millard AR (2014) Conventions for reporting radiocarbon determinations. Radiocarbon 52:555-559

Millard A (2019) The AMS dates, Section 4_9. https://doi. org/10.5284/1047597

Miller D (2019) The molluscan evidence, Section 3.5.4. https://doi. org/10.5284/1047597

Moore PD, Webb JA, Collinson ME (1991) Pollen analysis. Blackwell, Oxford

Müller J, Videiko MYu (2016) Maidanetske: new facts of a megasite. In: Müller J, Rassmann K, Videiko MYu (eds) Trypillia-megasites and European prehistory 4100-3400 BCE. EAA Monograph 2, Maney, Wakefield, pp 71-94

Müller J, Rassmann K, Videiko MYu (eds) (2016) Trypillia-megasites and European prehistory 4100-3400 BCE. EAA Monograph 2, Maney, Wakefield

Nebbia M, Gaydarska B, Millard A, Chapman J (2018) The making of chalcolithic assembly places: Trypillia megasites as materialized consensus among equal strangers? World Archaeol 50:41-61. https://doi.org/10.1080/00438243.2018.1474133

Novenko EYu, Volkova EM, Glasko MP, Zuganova IS (2012) Palaeoecological evidence for the middle and late Holocene vegetation, climate and land use in the upper Don River basin (Russia). Veget Hist Archaeobot 21:337-352

Orton DC, Nottingham J, Rainsford-Betts G, Hosking K (2019) The animal bones, Section 3.6.1. https://doi.org/10.5284/1047597

Pashkevitch G (1997) Early farming in Ukraine. In: Chapman J, Dolukhanov PM (eds) Landscapes in flux: Central and Eastern Europe in antiquity. Oxbow Books, Oxford, pp 267-274

Pashkevitch G (2005) Palaeoethnobotanical evidence of the Tripolye culture. In: Dumitroaia G, Chapman J, Weller O, Preoteasa C, Monteanu R, Nicola D, Monah D (eds) Cucuteni 120 years of research, time to sum up. Centrul de Cercetare a culturii Cucuteni, Piatra-Neamt, pp 213-245

Pashkevych G (2012) Environment and economic activities of Neolithic and Bronze age populations of the Northern Pontic area. Quat Int 261:176-182

Pashkevych G (2014) Data of the Trypillian agriculture: new palaeobotanical evidence. In: Dumitroaia G, Preoteasa C, Nicola C-D (eds) Cucuteni culture within the European Neo-Eneolithic context. International Colloquium, Cucuteni 130 Conference Abstracts. Constantin Matasă, Piatra Neamţ, pp 24-27

Pashkevych G, Videiko M (2006) Rilnytsto plemen Tripilskoi kulturi. NANU, Kiev Institute of Archaeology, Kiev

Rassmann K, Ohlrau R, Hofmann R, Mischka C, Burdo N, Videjko MYu, Müller J (2014) High precision Tripolye settlement plans, demographic estimates and settlement organization. J Neolit Archaeol 16:96-134

Rassmann K, Korvin-Piotrovskiy A, Videiko MYu, Müller J (2016) The new challenge for site plans and geophysics: revealing the settlement structure of giant settlements by means of geomagnetic survey. In: Müller J, Rassmann K, Videiko MYu (eds) Trypillia megasites and European prehistory 4100-3400 BCE. Routledge, New York, pp 29-54

Reimer PJ, Bard E, Bayliss A et al (2013) IntCal13 and Marine13 radiocarbon age calibration curves $0-50,000$ years cal BP. Radiocarbon 55:1,869-1,887

Robinson D (1984) The estimation of the charcoal content of sediments: a comparison of methods on peat sections from the Isle of Arran. Circaea 2:121-128

Sagar GR, Harper JL (1964) Plantago major L., Plantago media L. and Plantago lanceolata L. J Ecol 52:189-221

Shmagliy N (1980) Krupnye Tripolskie Poseleniya v Mezhdurechje Dnepra i Yuzhnogo Buga. In: Artemenko I (ed) Pervobytnaya 
Archeologiya Poiski I Nahodki. Naukova dumka, Kiev, pp 198-203

Shukurov A, Sarson G, Videiko M, Henderson K, Shiel R, Dolukhanov P, Pashkevich G (2015) Productivity of premodern agriculture in the Cucuteni-Trypillia area. Hum Biol 87:235-282

Shumilovskikh LS, Novenko E, Giesecke T (2017) Long-term dynamics of the East European forest-steppe ecotone. J Veg Sci $29: 416-426$

Stockmarr J (1971) Tablets with spores used in absolute pollen analysis. Pollen Spores 13:871-873

Troels-Smith J (1955) The characterization of unconsolidated sediments. Dan Geol Unders. Række IV 3:1-73

Turner J, Peglar SM (1988) Temporally-precise studies of vegetation history. In: Huntley B, Webb T III (eds) Vegetation history. Kluwer, Dordrecht, pp 753-777

Van Geel B (1986) Application of fungal and algal remains and other microfossils in palynological analyses. In: Berglund BE (ed) Handbook of palaeoecology and palynology. Wiley, New York, pp 497-505

Van Geel B (2001) Non-pollen palynomorphs. In: Smol JP, Birks HJB, Last WM (eds) Tracking environmental change using lake sediments. Vol 3: terrestrial, algal and siliceous indicators. Kluwer, Dordrecht, pp 99-119

Van Geel B, Buurman J, Brinkkemper O, Schelvis J, Aptroot A, van Reenen G, Hakbijl T (2003) Environmental reconstruction of a Roman period settlement site in Uitgeest (The Netherlands), with special reference to coprophilous fungi. J Archaeol Sci 30:873-883
Van Hoeve ML, Hendrikse M (1998) A study of non-pollen objects in pollen slides. The types as described by Dr. Bas van Geel and colleagues. Unpub MS, Utrecht

Videiko MYu (2012) Comprehensive study of the large settlements of the Tripolye culture: 1971-2011. Stratum Plus 2012:225-263

Videiko MYu (2013) Kompleksno izuchenie krupnih poselenii tripol'skoi kul'turi. Lambert Academic Publishing, Saarbrücken

Ward GK, Wilson SR (1978) Procedures for comparing radiocarbon age determinations: a critique. Archaeometry 20:19-31

Wilhelmy H (1950) Das Alter der Schwarzerde und der Steppen Mittelund Osteuropas. Erdkunde 4:5-34

Wood JR, Wilmshurst JM (2012) Wetland soil moisture complicates the use of Sporormiella to trace past herbivore populations. J Archaeol Sci 27:254-259

\section{Web references}

http://www.worldweatheronline.com/uman-weather-averages/cherk aska-oblast/ua.aspx

http://www.worldweatheronline.com/kirovograd-weather-averages/ kirovohradska-oblast/ua.aspx

Publisher's Note Springer Nature remains neutral with regard to jurisdictional claims in published maps and institutional affiliations. 